\title{
DOKLADY BOJOVEJ ČINNOSTI Z OBDOBIA 2. SVETOVEJ VOJNY V PRIESTORE MEDZI TRNAVOU A TRSTÍNOM (JUHOZÁPADNÉ SLOVENSKO). MOŽNOSTI APLIKÁCIE METÓDY KOCOA
}

\author{
Martin Neumann*
}

* Institút na výskum kultúrnej krajiny, Suchá nad Parnou 92, 91901 Suchá nad Parnou, martin.neumann@invykk.sk.

\begin{abstract}
Relics of WWII military activities in the area between Trnava and Trstín (South-western Slovakia). KOCOA and its applicability. At the recent time, the battlefield archaeology belongs to the slowly developing and establishing branches of Slovak archaeology. Thank to only few zealous researches gains this field of interest consistently more attractiveness among researchers. The main efforts are concentrated on describing and documentation of military activities or preservation and protection of battlefield relics. Nevertheless, researchers abroad focus on different issues and use spatial analyses to reconstruct or understand strategies of combatants. In the following text we try to demonstrate one of these analyses known as KOCOA. An area between Trnava and Trstín (South-western Slovakia) where on April 1945 German military troops tried to stop advancing Soviet units was chosen as a model area. By means of KOCOA analysis we will try to predict locations which were considered appropriate for defence. These locations, confronted with LiDAR-derived images, can provide evidence of field fortifications which can be subjected to subsequent scientific research, preservation and protection.
\end{abstract}

Keywords: Slovakia, Buková Pass, Horné Orešany, 2nd World War, battlefield archaeology, LiDAR, KOCOA

Abstrakt: $\mathrm{V}$ posledných rokoch patrí archeológia bojísk na Slovensku k pomaly sa etablujúcim odvetviam archeológie. Vd’aka zopár zanieteným jedincom získava aj v odborných kruhoch postupne čoraz viac pozornosti. Hlavná pozornost' je venovaná opisu a dokumentovaniu bojových akcií, resp. zachovaniu a ochrane reliktov po bojových činnostiach. Napriek tomu sa výskum $\mathrm{v}$ zahranič́ koncentruje vd’aka dlhodobému záujmu o archeológiu bojísk na rekonštrukciu a pochopenie stratégií bojujúcich strán pomocou priestorových analýz. V nasledujúcom texte je predstavená jedna z najčastejšie využívaných analytických metód, ktorá je známa pod akronymom KOCOA. Ako modelové územie bola vybraná oblast' medzi Trnavou a Trstínom (juhozápadné Slovensko), kde sa nemecké jednotky pokúsili začiatkom apríla 1945 zastavit' postup Sovietov. Prostredníctvom metódy KOCOA sa pokúsime predikovat' miesta vhodné na obranu. Konfrontácia vybraných lokalít s lidarovými snímkami má potenciál odhalit' prítomnost' doposial' zachovaných polných opevnení, ktoré sa tak môžu stat' predmetom d’alšieho výskumu a ochrany.

K'účové slová: Slovensko, Bukovský priesmyk, Horné Orešany, 2. svetová vojna, archeológia bojísk, LiDAR, KO$\mathrm{COA}$

https://doi.org/10.46283/musarch.2021.1.2.08

\section{1. Úvod}

Výskum bojísk novovekých a moderných konfliktov je v zahraničí už dlhodobo etablovanou oblast'ou záujmu archeologického bádania (úroveň stavu poznania a záujmu o problematiku archeológie bojísk na Slovensku vynikne napríklad z porovnania so situáciou v susednej Českej republike - pozri napr. Matoušek 2017; tam aj stručné porovnanie s inými krajinami). V posledných rokoch sa začínajú aj v slovenskom prostredí objavovat’ tendencie $\mathrm{k}$ cielenému 
výskumu miest historických vojenských stretov, hoci len vo vel'mi skromnej miere. Pozornost' je venovaná najmä atraktívnym témam či nie vel'mi dávnym konfliktom (preferovanou oblast'ou záujmu je dodnes stále pomerne nedávne obdobie 2. svetovej vojny, ktoré na Slovensku púta pozornost' nielen profesionálnych bádatelov, no i vel'kého množstva laikov). ${ }^{1} \mathrm{~V}$ dôsledku doterajšieho minimálneho zaujatia danou problematikou nie je preto prekvapivé, že sa výskum sústred'uje najmä na opis priebehu bojov, rozbor memoárovej literatúry, resp. identifikáciu dodnes viditel'ných reliktov po bojových aktivitách či spôsobu ich dokumentovania, prezentácie a ochrany (k tomu pozri napr. Bordác 2019; Šteiner 2020a; Šteiner 2020b). Cielenému a dlhodobému výskumu historických bojísk nie je však doposial' na Slovensku, až na ojedinelé výnimky, venovaná náležitá pozornost' (Bátora - Drozd 2019; Drozd 2019; Bordác 2020a; Bordác 2020b; Drozd - Neumann - Bátora 2020; Šteiner 2020c). Platí to napokon aj pre obdobie 2. svetovej vojny. Doterajšia prax ukazuje, že cielenému výskumu tohto historického obdobia nie je v slovenskej archeologickej obci venovaná náležitá pozornost'. Svetlou výnimkou sú aktivity Petra Ušiaka zamerané na vyhl’adávanie havarovaných lietadiel. Nádej na rozvoj tohto špecifického odvetvia v súčasnosti na Slovensku predstavuje najmä mladšia a stredná generácia bádatel’ov (Bordác 2020a; Šteiner 2020c).

Len náhodný výber aktivít z oblasti archeológie 2. svetovej vojny v susednej Českej republike poskytuje dostatočný pohl’ad na aktuálny stav bádania na Slovensku (trochu odlišný stav je na južnej Morave - pozri Zubalike. 2019). Českí kolegovia sa v súčasnosti neboja podnikat' aj rozsiahlejšie prieskumy a výskumy. Vd’aka ich aktivitám boli v českom Podkrušnohorí objavené a preskúmané relikty po rôznych vojenských zariadeniach (napr. protileteckých delách určených na obranu priemyselného zázemia Litvínova - k tomu pozri Krivánek - Čech - Soukup 2015). Už niekol'ko desat'ročí sa v českom prostredí postupne etabluje tzv. aeroarcheológia venujúca pozornost' havarovaným lietadlám (Rak 2010, 252-255; pozri aj najnovší nález trosiek lietadla Iljušin Il-2 v Karlove na Osoblažsku²). V posledných rokoch vzbudil celospoločenskú diskusiu archeologický výskum koncentračného tábora v juhočeských Letoch (Vařka 2018; Vařkea - Vařeková 2017). Vd’aka dlhodobejšiemu záujmu, možnostiam a úsiliu dnes už v Českej republike existuje dokonca samostatné univerzitné pracovisko špecializujúce sa na problematiku tzv. archeológie modernity (Katedra archeológie Západočeskej univerzity v Plzni). Dlhoročný výskum realizovaný jeho pracovníkmi ukazuje, že spektrum výskumných otázok týkajúcich sa (nielen) obdobia 2. svetovej vojny je naozaj široké (za všetky spomeňme napr. výskum hrobov vojnových obetí, hromadných hrobov, vojenských fortifikácií atd’. - pozri najmä Rak. 2013; Rak 2014). Je zrejmé, že aj na Slovensku bude vzhl'adom na legislatívnu úpravu definovania archeologického nálezu nevyhnutné zamerat' odbornú pozornost' na rovnaké výskumné otázky. V súčasnosti sa na Slovensku túto medzeru snažia aspoň čiastočne vyplnit’ svojimi aktivitami nadšení jednotlivci (s inštitucionálnym zastrešením), ${ }^{3}$ súkromné spolky či občianske združenia. ${ }^{4}$ Perspektíva d'alšieho výskumu je pritom naozaj vel'ká. Dokazujú to aj náhodné nálezy hrobov padlých nemeckých vojakov zo Svätého Jura a z priestoru medzi Bukovou a Trstínom (Čambal a kool. 2011, 79-80), ${ }^{5}$ alebo už uvedené aktivity M. Bordáča a P. Šteinera. Svetlú stránku predstavuje tiež skutočnost', že problematika archeológie bojísk začína na Slovensku svojou atraktivitou prit’ahovat' mladšie generácie, čo sa prejavuje v narastajúcom počte záverečných prác venujúcich sa obdobiu 2. svetovej vojny (Bordáč 2017; Hǒ̌ek. 2018; Majer 2018; Bordác 2020b; Hošek 2020; k tomu pozri aj Hošek 2019).

Kým výskum v rámci archeológie bojísk je na Slovensku stále ešte takpovediac in statu nascendi, zahraničné bádanie, majúc za sebou už desat’ročia intenzívneho výskumu, si dnes už kladie komplexné výskumné otázky. V popredí stojí predovšetkým analýza terénu vojenských stretov, vychádzajúca z postupov využívaných vojenskými stratégmi od začiatku 20. storočia (Scott-McFeaters 2011, 115). Potenciál priestorových analýz sa mnohonásobne zvýšil v súvislosti s ich aplikovaním v prostredí geograficko-informačných systémov (Kim a kol. 1994). Zohl’adnením viacerých

1 Dobrým príkladom dlhodobého aktívneho záujmu laickej verejnosti o problematiku 1. a najmä 2. svetovej vojny je Military Historical Museum v Pohronskom Ruskove (pozri www.mhmo.sk).

2 Aktívne vyhladávanie vrakov vojenských lietadiel realizujú pracovníci Leteckého múzea v Suchdole nad Odrou a Sekcia vojenskej histórie Klubu priatel'ov Suchdolu nad Odrou. Pre viac informácií pozri tu: https://www.leteckemuzeum.eu/ https://ct24.ceskatelevize.cz/3352658-nadsenci-na-osoblazsku-vykopali-stary-havarovany-sturmovik-rusky-bitevnik-byl-ctyri-metry

3 V rámci slovenskej archeológie je dodnes prehliadaný cielený výskum amerického lietadla typu Lockheed P-38J Lightning, ktoré v júni 1944 stroskotalo ned'aleko železničnej stanice Svätý Jur-Grinava. Časti lietadla i s telom pilota boli vyzdvihnuté začiatkom septembra 1990 členmi Klubu priatelov leteckej histórie pri Historickom múzeu SNM v Bratislave (- my-1991, 50).

4 Ako príklad uved'me aktivity Klubu priatel'ov turistiky (pozri tu: http://www.kpt.sk/clanky/opevnenia-v-malych-karpatoch-z-druhej-svetovej-vojny. html).

5 http://www.pamiatky.sk/sk/page/aktuality-kpu-trnava 
faktorov je tak možné približit' sa $\mathrm{k}$ dôkladnejšiemu pochopeniu zmýšlania a konania účastníkov konfliktu. Jedna $\mathrm{z}$ dnes preferovaných metód používaných na tento účel je metóda známa pod akronymom KOCOA. Názov je odvodený zo začiatočných písmen jej jednotlivých prvkov - klúčového terénu (Key terrain), pozorovania a palebného pokrytia priestoru (Observation and fields of fire), krytov a možností skrývania (Concealment and cover), prekážok (Obstacles) a koridorov prístupu (Avenues of approach). Z uvedeného vyplýva, že ide primárne o priestorovú analýzu (Spilý - Hrnčiar 2013, 47; Spennemann 2020, 753). Analyzovaním týchto prvkov a ich následnou syntézou možno dôjst' $k$ pochopeniu stratégie bojujúcich strán a prípadne aj priebehu bojov. $Z$ archeologického hladiska však môže táto metóda poslúžit' aj k predikovaniu výskytu terénnych reliktov spojených priamo s vedením bojových činností. $\mathrm{S}$ úspechom je táto metóda využívaná v anglo-americkom svete (napr. Woeblke - Hollon 2011a; Woeblke - Hollon 2011b; Sivilich 2012; Mastone - Brown - Maio 2015; Sivilich - Sivilich 2015; Carrell - Roth - McKinnon 2020), európske prostredie zatial' len začína objavovat' možnosti tejto metódy pre štúdium a rekonštrukciu historických a protohistorických vojenských stretov (napr. Brown a kol. 2017).

Účelom tejto štúdie má byt' experimentálna aplikácia metódy KOCOA na vybranom teréne s cielom predikcie, vyhl'adania a overenia prítomnosti terénnych reliktov po bojových činnostiach. Ako modelové územie bol vybraný priestor medzi Trnavou a Trstínom, kde v posledných mesiacoch 2. svetovej vojny (konkrétne začiatkom apríla 1945) niekol'ko dní prebiehala intenzívna bojová aktivita. Ciel’om sovietskeho vojenského velenia bolo dobytie Bukovského priesmyku ${ }^{6}$ a prechod na západnú stranu Malých Karpát. Nemecké vojenské velenie, ktoré potrebovalo zaistit' bezpečný presun ustupujúcich jednotiek operujúcich na dolnom Považí smerom na Záhorie, sa naopak snažilo čo najdlhšie udržat' tento priesmyk vo svojich rukách. Ciel'om tohto príspevku je zistit', či aktivity nemeckého vojenského velenia vedúce $\mathrm{k}$ obrane priestoru priesmyku sú predikovatel’né na základe metódy KOCOA, resp. či sú uvedené opatrenia (napr. stavba pol'ných opevnenî) identifikovatel'né pomocou priestorovej analýzy aj priamo v teréne. Výsledky tejto metódy budú konfrontované s d’alšími druhmi prameňov - historickými mapovaniami a najmä dnes už dobre dostupnými lidarovými snímkami?

\section{Priebeh bojov}

Bojové aktivity v okolí Bukovského priesmyku súvisia s finálnou fázou 2. svetovej vojny. Územie Slovenska sa dostalo do bezprostrednej pozornosti sovietskeho velenia v 2. polovici roka 1944. Armády 1., 2. a 4. ukrajinského frontu prekročili na jeseň hrebene Karpát a vstúpili do priestoru Karpatskej kotliny. Na zastavenie, resp. spomalenie tohto postupu sa velenie nemeckých vojsk rozhodlo vybudovat' v Karpatskej kotline niekol'ko obranných línií. Najvýchodnejšia z nich kopírovala západný breh Tissy. Druhá obranná línia viedla pozdľž pravého brehu Dunaja a v okolí Budapešti bola doplnená o opevnené predpolie na jeho lavom brehu. Posledná, tretia línia sa t’ahala pozdíž dnešných rakúsko-mad’arských hraníc a d’alej na severovýchod nadviazala na východné úpätia Malých a Bielych Karpát (Nejedlý 1978, 42). Nadväzovala na tzzv. Südostwall, ktorý sa t’ahal od sliezskeho mesta Żory až po Drávu. Jeho účelom bolo zamedzit' vstup sovietskym vojskám priamo na územie Ríše. Navyše, Nemci prejavovali eminentný záujem aj o ochranu priemyselnej zóny medzi Brnom a Ostravou (Šimončic 1979, 205).

Priamo na juhozápadnom Slovensku mal nemecký Wehrmacht vybudovaných niekol'ko menších predsunutých obranných línií, ktoré nechal budovat’ už od septembra roku 1944. Tieto línie sa opierali o prirodzené terénne prekážky, najmä rieky či pohoria, ktoré boli doplnené o systém umelých prekážok (Mabler - Broft 1984, 63). Predná obranná línia bola položená na dolnom Hrone, na ktorú bol kladený i najväčší dôraz. Nasledovali obranné línie na rieke Nitre, Váhu a napokon hlavná obranná línia v podhorí Malých a Bielych Karpát. V predpolí Malých Karpát boli vyhíbené dva zákopové pásy s drôtenými prekážkami. Medzi oboma pásmi bol priestor široký $2-3 \mathrm{~km}$, ktorý vypíñala protitanková priekopa. Za ňou boli ešte umiestnené železobetónové palebné ohniská (Nesvadba - Plubař 1962, 35).

V priebehu marca a apríla roku 1945 prekonávali sovietske vojská v rýchlom slede jednotlivé predsunuté obranné postavenia. Dňa 25. marca 1945 začali vojská 2. ukrajinského frontu s prechodom cez rieku Hron. Už o pät’ dní

6 Hoci priesmyk poskytuje prechod z Trstína nielen smerom na Bukovú, no i na Jablonicu, kvôli zjednodušeniu ho v texte nazývame ako Bukovský priesmyk.

7 Dostupné na: https://www.geoportal.sk/sk/sluzby/aplikacie/mapovy-klient-zbgis/ 
neskôr sa prvé sovietske jednotky preplavili pri Šali na pravý breh Váhu. Začiatkom apríla spresnilo hlavné sovietske velenie útočný smer hlavných síl severne od Dunaja. Ten mal viest' na Malacky, Hodonín a Brno. V ceste d’alšiemu postupu však stála Bratislava. Velitel' 2. ukrajinského frontu maršal Rodion J. Malinovský sa ju rozhodol obk'účit' zo severozápadu. To vyžadovalo prechod na západnú stranu Malých Karpát. Najschodnejšiu a najbližšiu cestu na prechod cez pohorie predstavoval Bukovský priesmyk, ktorý sa tak zakrátko dostal do centra pozornosti sovietskeho velenia (Šimončic 1979, 205).

V smere na Trnavu a Bukovský priesmyk operovala 1. gardová jazdecko-mechanizovaná skupina generálporučíka Issu A. Plijeva. Súčast'ou skupiny bol 4. a 6. gardový jazdecký zbor a 23. tankový zbor (Šimončic 1979, 204-205). V sobotu 31. marca boli sovietskymi lietadlami od skorých ranných hodín bombardované nemecké jednotky, ktoré ustupovali cez Trnavu d’alej na západ. Nasledujúci deň bombardovanie pokračovalo až do poobedia, kedy do mesta vstúpili prvé sovietske jednotky a oslobodili ho (Pauliak 1980, 92; Horváth 1987, 49). Pripravované zátarasy a protitankové prekážky, priekopy či betónové ihlany, ktoré boli vybudované juhovýchodne od mesta, no i priamo v jeho centre, nespôsobili výraznejšie spomalenie postupu Sovietov (Horváth 1987, 49; Šimončic 1979, 203). Nemecké jednotky v tejto situácii bezhlavo ustupovali k obrannej línii pod Malými Karpatmi. Plánom Sovietov bolo do dvoch dní prekročit' Karpaty a vytvorit' predmostie v Hodoníne (Kožuch 1965, 8). Ešte v nedelu 1. apríla sa podarilo severozápadne od Trnavy (smerom na Bukovský priesmyk) oslobodit’ obce Zvončín, Suchá nad Parnou a Košolná (Mišuth 2014, 41).

Po dobytí Trnavy večer 1. apríla 1945 postupoval 4. gardový jazdecký zbor d’alej na severozápad smerom k úpätiu Malých Karpát. V ceste cez Bukovský priesmyk im stála nemecká pancierová divízia Feldherrnhalle 2, ktorá sa sem presunula z okolia Nových Zámkov. Jej súčast’ou bol i 93. granátnický pluk. Divízne velenie umiestnilo velitel’stvo pluku po stiahnutí sa z Trnavy do Bolerázu, odkial' koordinovalo obranu predpolia Bukovského priesmyku (Jordan 2015, 26). Pluku bola podriadená aj jednotka obrnených vozidiel SPW na južnom okraji Dolných Orešian.

Nemecká obrana sa na príchod sovietskych vojsk dobre pripravila. Pred vstupom do Bukovského priesmyku vybudovala 2 pásy zákopov, menšie pevnosti, protitankové priekopy a pásy drôtených zátarás. Velmi účinné boli najmä protitankové priekopy. Ked’ sa tanky 10. jazdeckej divízie (4. gardového zboru) priblízili k línii Horné Orešany - Klčovany, narazili na jednu z protitankových priekop, ktorá zabránila ich d’alšiemu postupu. Len vd’aka obetavosti miestneho obyvatel'stva z Horných Orešian, ktoré sa počas neustálej pal'by vydalo na pomoc sovietskym tankom, sa podarilo vytvorit' pre sovietske tanky niekol'ko priechodov (Nesvadba - Pluhar 1962, 50). Sovietski gardoví vojaci museli postupne vytláčat' nemeckých vojakov z pozícií, ktoré si vybudovali severne od Horných Orešian na vrchu Všivavec (Pauliak 1980, 95). Ešte v ten istý deň (2. apríla) boli nemeckí vojaci nútení sa stiahnut' z Lošonca, Smolenickej Novej Vsi, Klčovian a Bolerázu (Šmončič 1979, 212; Babirát 1996, 189). Čast' z nich bola Plijevovými gardovými jazdcami nahnaná do malokarpatských lesov, kde boli zneškodnení partizánmi (Pauliak 1980, 95). Zvyšok nemeckých jednotiek sa uchýlil do Smoleníc, kde sa pripravovali na d’alší sovietsky útok. Sovietske vojská v tomto momente (2. apríla) delili od Bukovského priesmyku len obce Trstín a Smolenice. Práve tam sa v nasledujúcich dňoch strhli aj najprudšie boje. Frontová línia sa posúvala cez intravilán Smoleníc viackrát oboma smermi. Dôkladne vybudované nemecké pozície dočasne zbrzd’ovali postup sovietskych vojakov (Jastrabík. 1975, 167). Pre nemecké velenie bolo dôležité udržat' Bukovský priesmyk čo najdlhšie vo svojich rukách, aby tým umožnili stiahnutie viacerých peších divízií z východu (Jordan 2015, 27). Situácia začala byt' neudržatel’ná 4. apríla. Velitel'stvo divízie Feldherrnhalle sa presunulo na kótu 340, ktorá sa nachádzala už v západnej časti priesmyku. Od popoludňajších hodín začali nemecké jednotky priestor priesmyku a jeho východného predpolia opúšt'at', čo bolo sprevádzané sovietskym ostrelovaním Trstína. Týmto spôsobom sa s podporou 264. bojovej leteckej divízie podarilo postupne ovládnut' celý priestor priesmyku, zajat' 208 vagónov s proviantom, krmivom a muníciou, a ovládnut' obilné silo, ktoré ustupujúce nemecké a mad’arské vojská nestihli vyhodit’ do vzduchu (Plijev 1975, 9). Večer toho istého dňa bol priesmyk už v sovietskych rukách (Jordan 2015, 27).

\section{KOCOA - význam a aplikácia}

Z hore uvedeného opisu udalostí je zrejmé, že boje o Bukovský priesmyk mali viacdňový priebeh. Nemecké velenie malo možnost' sa niekol'ko mesiacov vopred pripravit' na obranu tohto priestoru, čo, samozrejme, v plnej miere 
využilo. Prítomnost' pol’ných opevnení v oblasti medzi Trstínom a Trnavou je teda viac než istá. Na identifikovanie či predikovanie ich prítomnosti v súčasnom teréne bude využitá metóda KOCOA. Ako už bolo vyššie spomenuté, táto metóda je primárne priestorovou analýzou, ktorá reflektuje viacero faktorov (Spilý - Hrnčiar 2013, 47; Spennemann 2020,753). Pred jej aplikáciou na konkrétnom príklade je nutné si objasnit’ význam jej základných elementov.

\section{Klúčový terén}

Pod pojmom klúčový terén možno chápat' akékolvvek miesto, ktorého obsadenie poskytuje jednej z bojujúcich strán určitú výhodu pri plnení jej ciel’a. Vo väčšine prípadov je takéto miesto stotožňované s akoukol'vek vyvýšenou polohou, ktorá poskytuje dobrý rozhl'ad do okolia. Kl'účový terén však nemusí byt' výhradne terénnou dominantou, ktorá kontroluje široké okolie. Možno pod ním chápat’ aj strategické križovatky, mosty či koridory, ktorých získanie by protivníkovi umožnilo obídenie pozícii či pret’atie zásobovacích trás. Hoci klúčový terén zohráva vd’aka svojmu strategickému významu počas bojových operácií dôležitú úlohu, nemusí byt' nutne priamo obsadený obrannými jednotkami. V niektorých prípadoch postačuje len jeho kontrola z určitej vzdialenosti či účinné zamedzenie prístupu k nemu pomocou vhodných prekážok (Spennemann 2020, 754).

2. Pozorovanie a palebné pokrytie priestoru

So zabezpečením klúčového terénu úzko súvisí pozorovanie a palebné pokrytie priestoru. Pre sledovanie približujúceho sa protivníka či rozmiestnenia jeho jednotiek je najvhodnejšie zaujat’ také postavenie, ktoré poskytuje čo najlepší výhl'ad. Vždy je však nutné zvážit' aktuálne podmienky, ktoré ovplyvňujú viditel’nost' (terén, počasie, vegetácia). Č́m väčší a širší je pozorovaný priestor, tým je možné získat’ viac informácíi o protivníkovi a jeho plánovaných aktivitách. To následne umožňuje aj lepšiu prípravu na nepriatel'ský útok. Pozorovaný priestor by mal byt' v ideálnom prípade zaistený pal'bou. Vel'kost' takto pokrytého priestoru vždy závisí od druhu použitých zbraní a ich efektívneho dostrelu (Spennemann 2020, 754).

3. Kryty a možnosti skrývania

Pred pal'bou nepriatel’a a pozorovaním je možné sa bránit' krytmi a skrývaním. Pred pal'bou protivníka chránia rôzne druhy krytov (cover) - budovy, múry, vyvýšené vozovky, úvozy, jaskyne, priekopy, terénne vlny a mnohé d'alšie terénne útvary. Oproti krytom poskytuje skrývanie (concealment) len úkryt pred nepriatel’ským pozorovaním, nie pred pal'bou. Aj v dôsledku toho je paleta rôznych druhov skrývania vel'mi široká. Možno k nej zaradit' lesný porast, kroviny, akúkol’vek dostatočne vysokú vegetáciu, snehové záveje a podobne (Spennemann 2020, 754).

4. Prekážky

Bariéru pre pohyb protivníka predstavujú prekážky. Slúžia na zastavenie a spomalenie postupu protivníka alebo jeho odklonenie do priestoru, ktorý je vhodnejší na obranu. Spektrum prekážok je rovnako vel’mi pestré. Môže obsahovat’ prírodné ako aj umelé prekážky. K prírodným patria napr. lesy, svahy či vodné toky, k umelým akákolvek zástavba, priehrady, priekopy, mínové polia a podobne (Spilý - Hrnčiar 2013, 47; Spennemann 2020, 754).

5. Koridory prístupu

Komunikácie spájajúce hlavnú bojovú zónu s logistickým zázemím, ktoré umožňujú prísun bojového materiálu, vojenských rezerv, no zároveň poskytujú priestor pre prípadný ústup, sa nazývajú koridory prístupu (Spennemann 2020, 754). Tie predstavujú zároveň aj priestor pravdepodobného prístupu protivníka $\mathrm{k}$ dosiahnutiu svojho ciel’a. Obrancovia klúčového terénu musia venovat' pozornost' práve týmto koridorom a zhodnocovat' jeho výhody z pohladu obrancu i útočníka. Vyhodnotenie koridorov prístupu a klúčového terénu následne umožňujú zvolit’ vhodné obranné pozície. Tie by mali byt' zároveň vhodným pozorovacím stanoviskom, dostatočným úkrytom pre obrancov, no zároveň by takto zvolené miesta mali poskytovat’ aj dostatočné palebné pokrytie okolitého terénu.

\section{Analýza}

Ako bolo vyššie spomenuté, metóda KOCOA je predovšetkým priestorovou analytickou metódou. V dôsledku toho je nutné pracovat' so zodpovedajúcimi nástrojmi. Pre účely priestorových analýz bol využitý program QGis 3.4, ktorý poskytuje široké spektrum vol’ne dostupných nástrojov na spracovanie priestorových údajov. Mapové pod- 


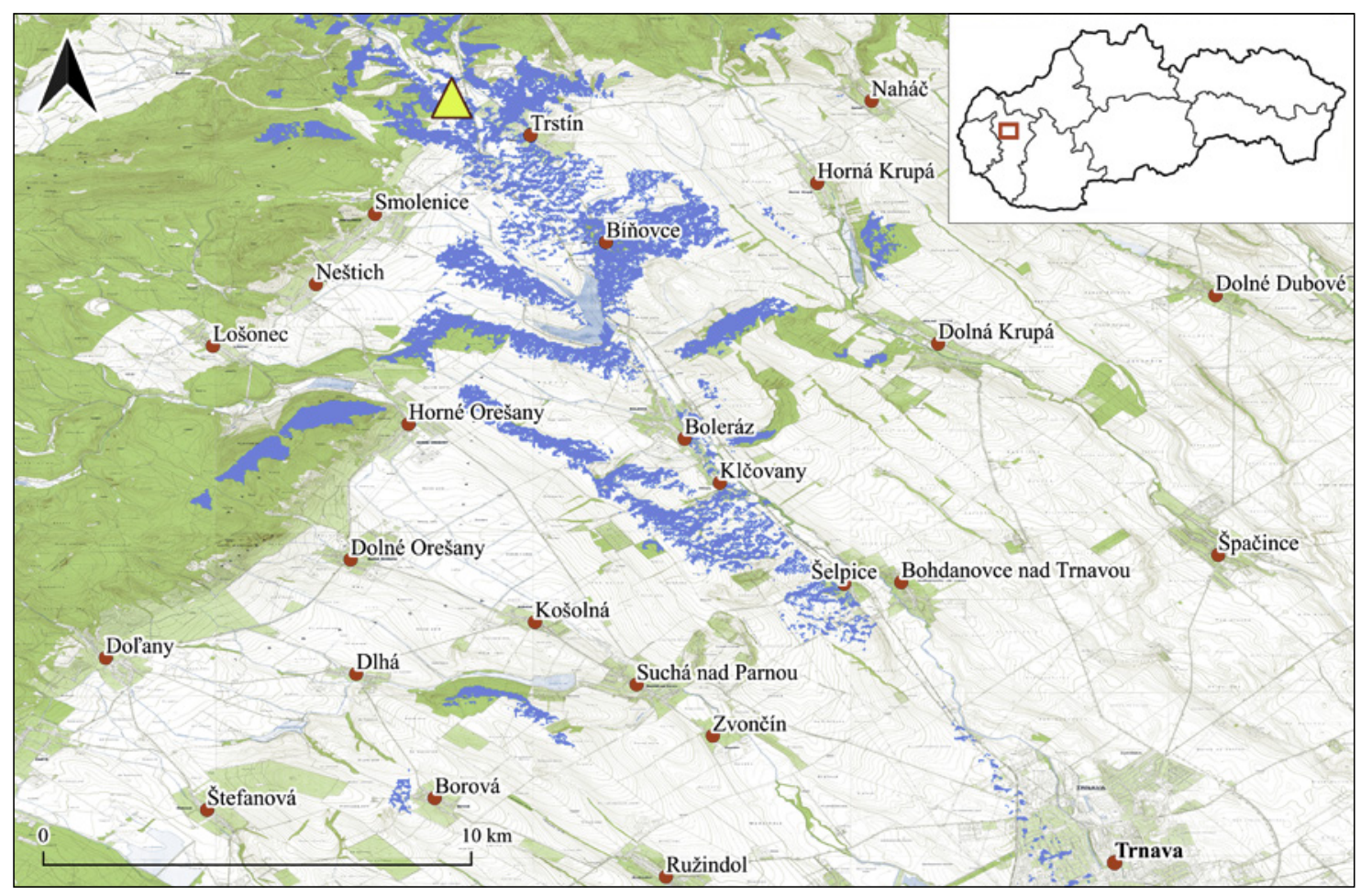

Obr. 1. Analýza viditel'nosti z východného vstupu do Bukovského priesmyku (miesto rozhladu označuje žltý trojuholník). Viditel’né územie je vyznačené modrou farbou (grafická úprava: M. Neumann).

Fig. 1. Viewshed analysis taken from the eastern entrance of Buková Pass (yellow triangle denotes a viewing position). Visible area is in blue (graphics by M. Neumann).

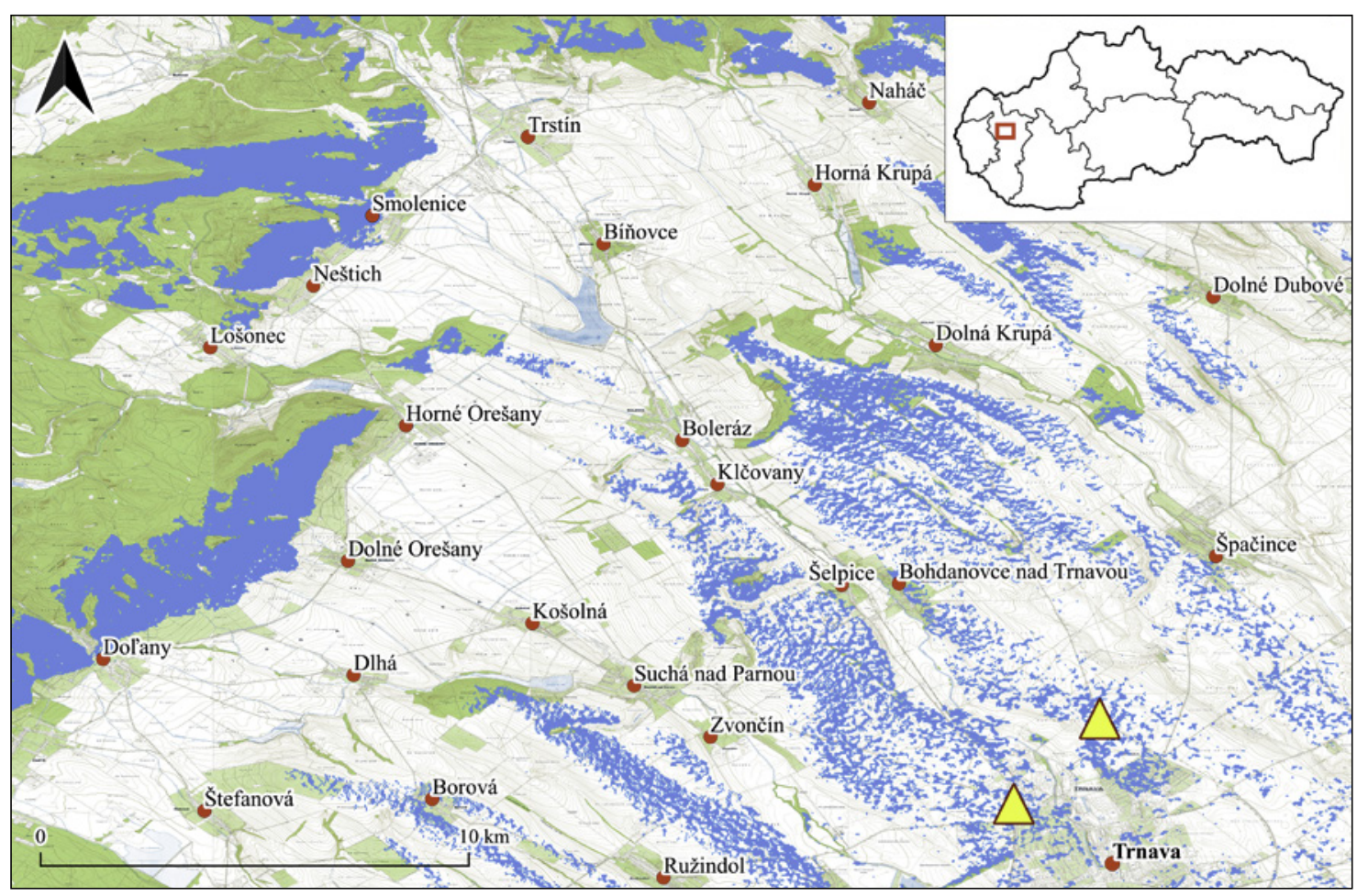

Obr. 2. Analýza viditel’nosti zo západných a severných predmestí Trnavy (miesta rozhl'adu označujú žlté trojuholníky). Viditel’né územie je vyznačené modrou farbou (grafická úprava: M. Neumann).

Fig. 2. Viewshed analysis taken from the western and northern outskirts of Trnava city (yellow triangles denote a viewing positions). Visible area is in blue (graphics by M. Neumann). 
klady použité pri viacerých priestorových analýzach (ZM $1: 10$ 000) boli získané z vol’ne dostupných WMS služieb poskytovaných Geodetickým a kartografickým ústavom Bratislava. ${ }^{8}$ Pri analýzach viditelnosti bol využívaný vol'ne dostupný digitálny výškový model prístupný na stránkach USGS (rozlišenie $30 \mathrm{~m}$ ). ${ }^{9}$ Ten tvoril základ aj pre vytvorenie vrstevnicového plánu (základný interval $5 \mathrm{~m}$ ). Pri analýze viditel'nosti z Bukovského priesmyku, zo západného a severného predmestia Trnavy ako aj z identifikovaných pol’ných opevnení sme $\mathrm{v}$ miestach pozorovania počítali výškou pozorovatel’a $1,75 \mathrm{~m}(o b r .1,2,7)$. Zakrivenie Zeme a jeho vplyv na viditel'nost' sa pri výpočte aj v dôsledku relatívne malého záujmového územia nezohladňovalo.

Podkladom pre tvorbu digitálneho modelu terénu bolo mračno bodov, ktoré bezplatne poskytuje Ústav geodézie, kartografie a katastra SR na svojom webovom portáli. Získané dáta boli spracúvané vol’ne dostupným softvérom CloudCompare, ktorý údaje podla potreby aj d’alej klasifikoval. Ako klasifikačná trieda bola pre účely tejto štúdie použitá trieda č. 2 (Ground). Vyfiltrované mračno bodov bolo prevedené do rastrovej podoby s rozlíšením $0,25 \times 0,25 \mathrm{~m}$ a pre d’alšie účely prezentované $\mathrm{v}$ podobe tieňovaného reliéfu (Hillshade).

Po stručnej charakteristike jednotlivých prvkov metódy KOCOA a použitého postupu práce je možné pristúpit' $\mathrm{k}$ ich aplikovaniu na vybranej oblasti medzi Trnavou a Trstínom. Hlavným cielom bude overenie využitelnosti uvedenej metódy v praxi a predikcia možnej prítomnosti reliktov po pol’ných opevneniach priamo v teréne. Ked’že obranu prístupu k priesmyku pripravovalo nemecké velenie, vychádza nasledujúca analýza práve z jeho perspektívy.

Nepopieratelným ciel’om nemeckých vojenských jednotiek nasadených na obranu priesmyku bolo jeho čo najdlhšie udržanie. Strategický význam Bukovského priesmyku vynikne pri pohl’ade na širší geografický kontext. Rovinaté územie juhozápadného Slovenska je od Devínskej brány smerom na severovýchod pret’até horským pásmom Malých Karpát. Hoci ide o pomerne nevysoký horský pás, pre spojenie Považia a Pomoravia predstavuje pomerne výraznú prekážku. Túto terénnu danost' si v plnej miere uvedomovali aj nemeckí vojenskí stratégovia. Preto bolo už v marci 1939 obsadené územie medzi západnou hranicou novovzniknutého Slovenského štátu a východnými úpätiami Malých Karpát, Bielych Karpát, Javorníkov a Západných Beskýd (na niektorých miestach bolo obsadené aj územie na l'avom brehu Váhu). Táto oblast' sa stala základom tzv. Ochrannej zóny (Schutzzone), ktorej existencia bola ukotvená v Dohode o ochrannom pomere medzi Slovenskom a Nemeckom z marca 1939 (Hešterová 2015, 183).

V roku 1944 bolo s blíżiacim sa východným frontom zrejmé, že ani územiu juhozápadného Slovenska sa boj nevyhne. Nemecké vojenské velenie si uvedomovalo, že po úspešnom prechode Slovenskom by sovietske vojská vkročili bezprostredne na územie Ríše. Bolo preto nevyhnutné ich čo najskôr zastavit’ či zdržat'. Ako jedna z najpríhodnejšćch prekážok sa v oblasti juhozápadného Slovenska javilo práve horské pásmo tiahnuce sa na východnej hranici Ochrannej zóny. Pozdíž jeho východného okraja sa od druhej polovice roka 1944 začalo s opevňovacími prácami. Budovaná obranná línia mala byt' súčast’ou tzv. Südostwall-u, ktorý sa na území Slovenska tiahol od Jablunkova po Bratislavu (Stelzl-Marx 2012, 131).

Vyše dvestokilometrové horské pásmo však nebolo nepreniknutel’nou prekážkou. Naprieč ním viedlo viacero priesmykov, ktoré umožňovali spojenie $\mathrm{v}$ smere východ - západ. V rámci Malých Karpát bolo využívaných viacero schodných koridorov, pričom jednu z najkratších a najschodnejších ciest predstavoval priesmyk medzi Trstínom a Bukovou, resp. Jablonicou. Krátky pohl’ad na vojenské mapovania Uhorska v tejto oblasti dokladá častú zmenu komunikačných trás, čo len potvrdzuje vysokú frekvenciu využívania tohto priesmyku (Janšák. 1986, 68-72; Cendelín 2019). Spevnená hradská cesta spájajúca Trstín a Bukovú tu bola vybudovaná už v rokoch 1885-1890 (Janšák 1963, 189). Využitie priesmyku sa ešte zintenzívnilo po tom, čo bola v roku 1898 otvorená železničná trat' prepájajúca Trstín s Jablonicou (Engler 2017, 383). Jej priebeh kopírovala aj nová cestná komunikácia, ktorej výstavba bola ukončená v roku 1938 (Janšák 1963, 187). Vd’aka kvalitne vybudovanej cestnej sieti v tomto priestore bolo vysoko pravdepodobné, že práve tento priesmyk sa stane jedným z ciel’ov jednotiek 1. gardovej jazdecko-mechanizovanej skupiny, ktorá na jar roku 1945 postupovala naprieč Trnavskou pahorkatinou v smere Trnava - Jablonica (Pauliak. 1980, 90).

Zámerom nemeckého vojenského velenia bolo čo najdlhšie udržanie Bukovského priesmyku. Vyžadovala si to prítomnost' viacerých nemeckých jednotiek v oblasti Považia, ktoré sa ešte nestihli stiahnut' na Záhorie. V prípade, že by sa priesmyk dostal do sovietskych rúk, hrozilo by nielen odrezanie týchto jednotiek východne od Malých Karpát, no zároveň by sa sovietskemu veleniu otvorila možnost' prerušenia ústupovej komunikácie z Bratislavy smerom

8 Dostupné na: https://www.geoportal.sk/sk/sluzby/mapove-sluzby/wms/

9 Dostupné na: https://earthexplorer.usgs.gov/ 


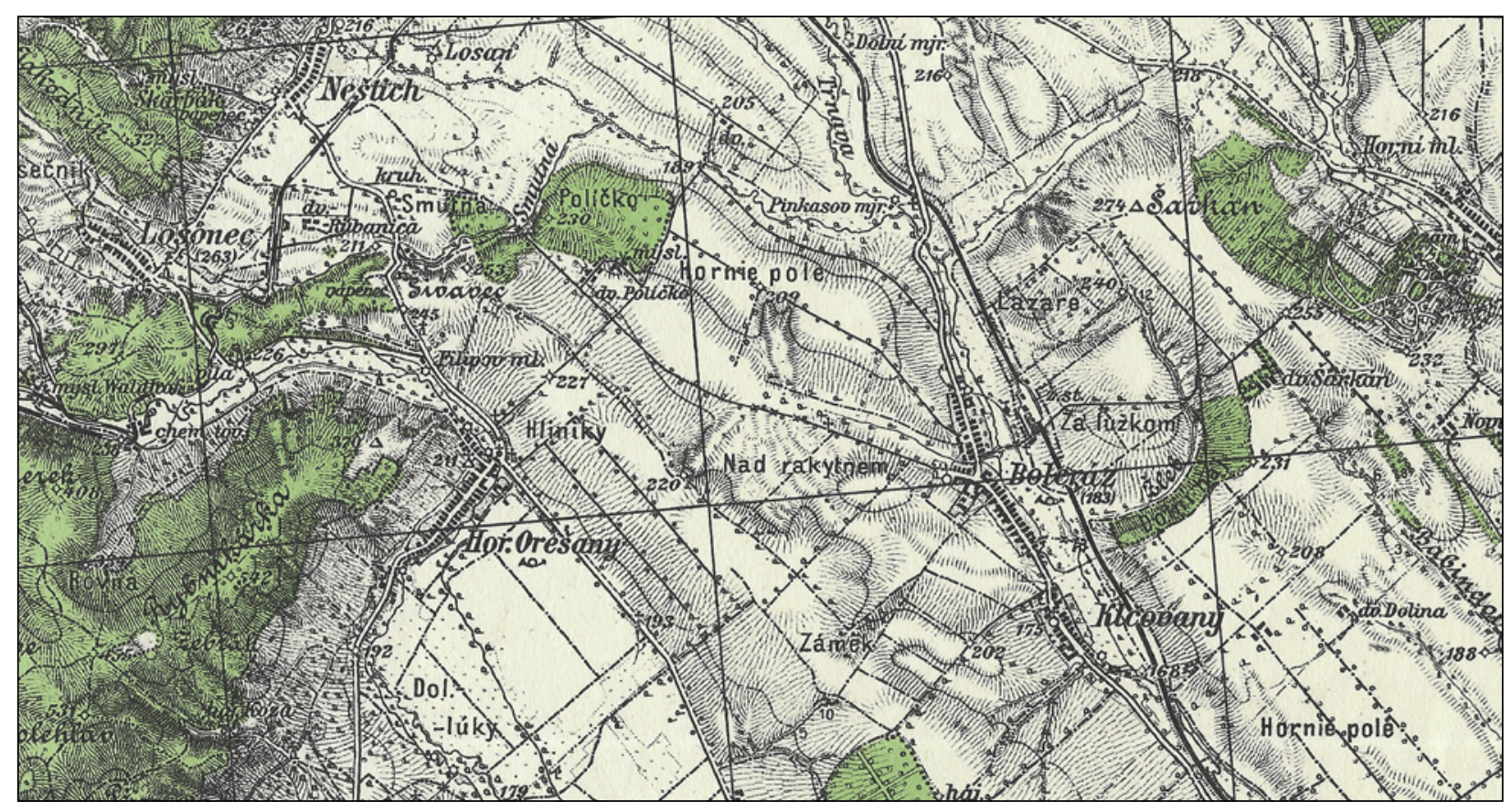

Obr. 3. Oblast' medzi obcami Lošonec a Boleráz na reambulovanej mape z roku 1938 (1: 75 000).

Fig. 3. Area between Lošonec and Boleráz on the reambulated map from 1938 (1: 75 000).

na Břeclav. Zvyšky nemeckých peších divízií brániacich „Festung Bratislava“ by sa následkom toho dostali do obklúčenia. Udržanie Bukovského priesmyku bolo preto pre nemecké vojenské velenie kriticky dôležité.

Hoci ciel'om nemeckého velenia bolo udržanie priesmyku, ten nepredstavoval z pohl’adu metódy KOCOA primárny klúčový terén. Vynikne to z topografie terénu medzi Trnavou a Trstínom. Z priestoru vstupnej časti do priesmyku je smerom na juhovýchod (smerom na Trnavu) len pomerne obmedzený výhlad (obr. 1). Bránia mu výbežky Malých Karpát pri Trstíne a Horných Orešanoch ako i vysoké sprašové chrbty medzi Bíňovcami a Bolerázom. Ak by 1. gardová jazdecko-mechanizovaná skupina využila pri svojom presune vhodné komunikačné trasy, mohla by sa nepozorovane presunút' z Trnavy až do Bíñoviec (len $5,5 \mathrm{~km}$ od vstupu do priesmyku). V prípade využitia cesty smerom od Naháča či Horných Orešian by sa sovietski jazdci generála I. A. Plijeva dostali do zorného pola obrancov priesmyku až vo vzdialenosti $1,5 \mathrm{~km}$ od jeho vstupu. Spolahnutie sa výhradne na obranu samotného vstupného koridoru do priesmyku by následkom toho mohlo mat' nielen pre jeho obrancov, no najmä pre nemecké divízie brániace Bratislavu fatálne dôsledky. V dôsledku toho bolo nutné zabezpečit' nielen priesmyk, no predovšetkým jeho bezprostredné predpolie. Práve toto predpolie, resp. jeho vonkajšia línia bola z nemeckého pohl’adu kl'účovým terénom, ktorý bolo nutné po stiahnutí sa z Trnavy bránit’ a čo najdlhšie udržat'.

Vonkajšiu hranicu tohto predpolia vopred určili prírodné danosti Trnavskej pahorkatiny medzi Trstínom a Trnavou. Terénne bariéry, ktoré bránili pohl’adu na Trnavu (smerom od priesmyku) boli zároveň vhodnými lokalitami poskytujúcimi dobrý výhlad do širokého okolia, no najmä smerom na juhovýchod. Dokladá to i analýza viditel'nosti smerom z Trnavy (obr. 2). Z jej západných predmestí bola bez problémov viditel'ná takmer $10 \mathrm{~km}$ dlhá oblast' až po líniu Boleráz - Dolná Krupá. Vizuálnemu prepojeniu s Bukovským priesmykom bránili svahy vrchu Šarkan a z jeho severnej i západnej strany vyčnievajúce sprašové chrbty Podmalokarpatskej pahorkatiny. Priestor obranného predpolia - oblast' medzi Bolerázom a Trstínom - tak bol pre blíziacu sa 1. gardovú jazdecko-mechanizovanú skupinu doslova „neviditel'ný“".

Predbežná identifikácia klúčového terénu (t. j. obranného predpolia priesmyku) tak zúžila možnosti lokalizácie nemeckých obranných stanovísk. K bližšej špecifikácii potenciálnych miest vhodných na obranu (a tým pádom aj prípadných terénnych reliktov po pol’nom opevnenî) poslúži zohladnenie najlepších koridorov prístupu k Bukovskému priesmyku. Tých existovalo v sledovanom období niekol'ko (obr. 3). Najjužnejš́i z nich predstavovala cesta vychádzajúca z Horných Orešian, ktorá sem viedla priamo z Trnavy (cez Suchú nad Parnou). Obec opúšt’ala na jej severnom okraji a viedla d’alej na severozápad k vrchu Všivavec (256 m n. m.). Komunikácia viedla naprieč vrchom 
a prekonávala aj potok Smutná na jeho severnom úpätí. Alternatívou $\mathrm{k}$ výstupu na vrch Všivavec bola komunikácia pozdĺž južného okraja Igramského hája, kadial' viedla cesta $\mathrm{k}$ obci Lošonec, no zároveň aj k chemickej továrni na Majdane, ktorá sa ukrývala v údolí potoka Parná. Továreň bola od svojho založenia v 80 . rokoch 19 . storočia zameraná na výrobu acetónu, formaldehydu, drevného liehu, dechtu, olejov a lakov, no počas existencie Slovenského štátu sa špecializovala na produkciu olejových farieb a emailov, tmelov, tužidiel, fermeže, riedidiel, sušidiel a lepidiel. So svojou dcérskou továrňou v Dobrej Vode bola spojená úzkokolajnou železnicou, ktorá viedla cez Trstín (Črč 1975, 160; Drahoš 2006, 105).

Druhá prístupová cesta viedla cez Boleráz smerom na severozápad. Predstavovala najfrekventovanejšiu a zároveň hlavnú prístupovú komunikáciu vedúcu z Trnavy smerom na Trstín. V hrubých rysoch kopírovala tok Trnávky. Od Trnavy až po Boleráz viedla komunikácia po jej pravom brehu, no medzi Bolerázom a Bíňovcami, v priestore zúženého profilu údolia Trnávky, prechádzala cesta na jej l’avý breh, ktorého sa držala až po Trstín. Rovnaký koridor využívala aj železnica, spájajúca Trnavu cez Bukovský priesmyk s Kútmi (Engler 2017, 383).

Vhodný koridor pre vstup do predpolia priesmyku predstavovala aj komunikácia vedúca v povodí Krupského potoka. Kritickým úsekom bol priestor medzi vrchom Šarkan a Horným hájom. Komunikácia musela prekonat' dva vodné
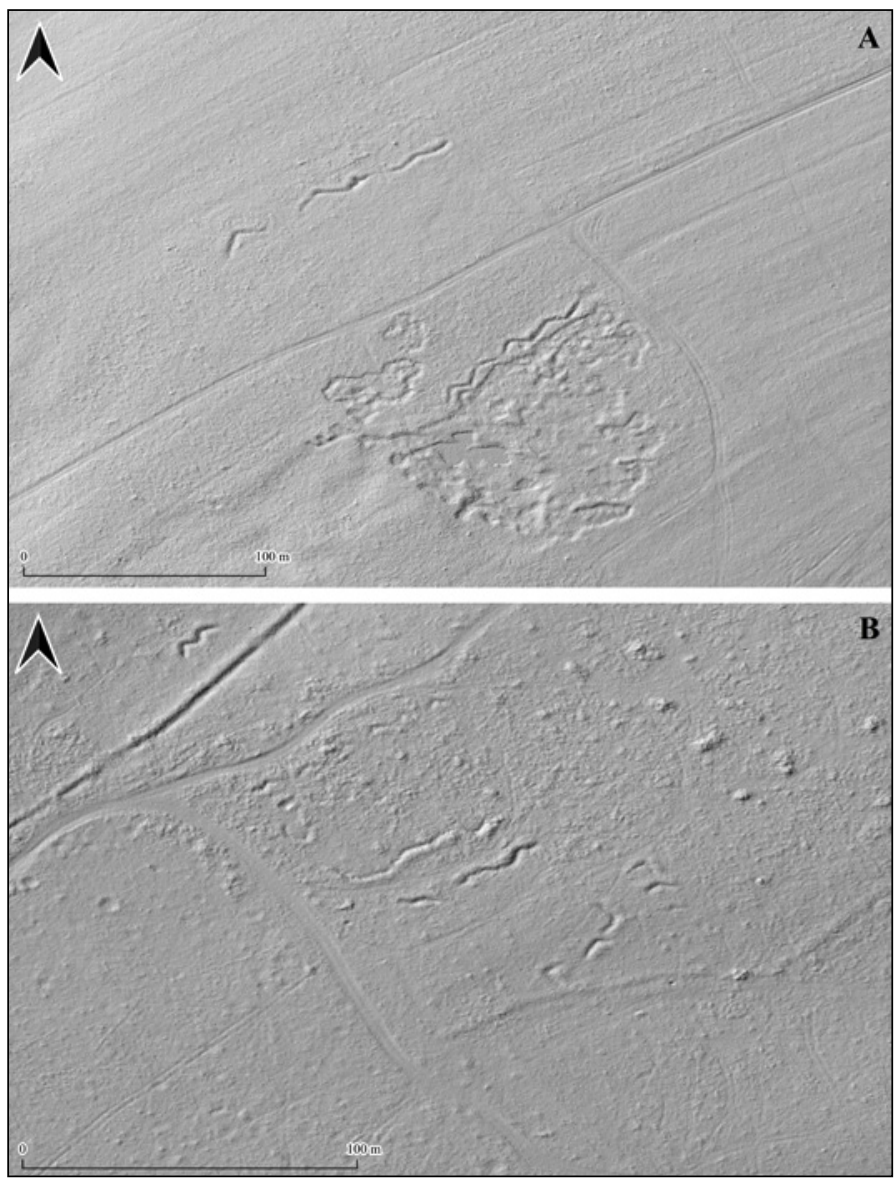

Obr. 4. A - Digitálny model terénu vrchu Šarkan. B - Digitálny model terénu v polohe Horný háj. Zdroj produktov LLS: ÚGKK SR (grafická úprava: M. Neumann).

Fig. 4. A - Digital terrain model of Šarkan. B - Digital terrain model of Horný háj. Source of LLS products: ÚGKK SR (graphics by M. Neumann). toky - Krupský potok a následne i Krupicu. Po prekonaní oboch vodných prekážok viedla cesta do obce Horná Krupá a odtial k úpätiu Malých Karpát, kde sa napájala na hlavnú podhorskú komunikáciu. Tá bola aj hlavným komunikačným koridorom smerom z východu (zo smeru Dechtice - Naháč).

Stanovenie najdôležitejších koridorov prístupu umožňuje vyčlenit’ konkrétne oblasti, kde možno očakávat' prítomnost' zvyškov obranných pol’ných opevnení. Na takto úzko ohraničené oblasti je už možné zamerat' väčšiu pozornost' a konfrontovat' ich s lidarovými snímkami. Práve takéto porovnanie ukazuje, že terénne zásahy, ktoré možno stotožnit' so zvyškami pol'ného opevnenia, sa dodnes nachádzajú severne od obce Dolná Krupá na úpätí terénneho chrbta (poloha Horný háj) a na vrchu Šarkan severovýchodne od obce Boleráz (obr. 4). Najvýraznejšiu koncentráciu terénnych reliktov je však možné zachytit’ na vrchu Všivavec severne od Horných Orešian a v katastri susednej Smolenickej Novej Vsi v polohe Smutná.

Ďalší prvok v rámci metódy KOCOA tvoria prekážky. Tie môžu byt' prírodného pôvodu alebo umelo vytvorené. K prírodným prekážkam v nami sledovanej oblasti možno priradit’ lesy, strmé svahy či vodné toky, ktoré mali spomal'ovat' sovietsky postup. Pomocnú ruku pri ich identifikácii podávajú najmä dobové mapovania, z ktorých možno rekonštruovat' aktuálny stav krajiny. Najvhodnejšími sú v našich podmienkach reambulované špeciálne mapy z roku 1938 (v mierke 1 : 75 000) a letecké mapovanie z roku 1950. ${ }^{10}$ Prírodné prekážky, ktoré sčasti možno vidiet' $\mathrm{v}$ teréne aj dnes, sa nachádzali už na samotnom južnom okraji hranice predpolia priesmyku severne od Horných 


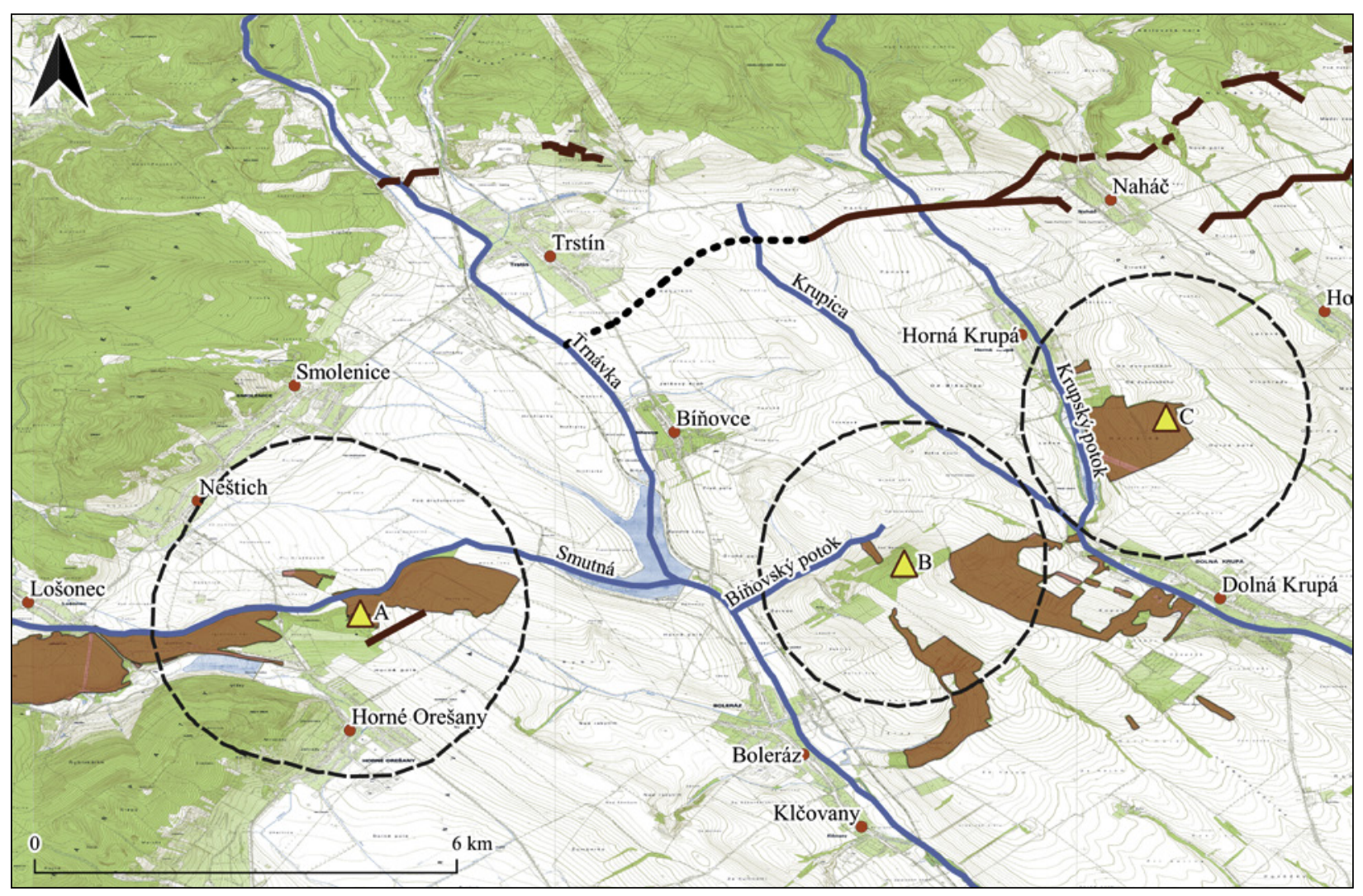

Obr. 5. Juhovýchodné predpolie Bukovského priesmyku. Hnedé plochy predstavujú stav lesných porastov v roku 1950. Identifikované relikty pol'ných opevnení sú označené písmenami (A - vrch Všivavec a poloha Smutná; B - vrch Šarkan; C - Horný háj). Pre každú z identifikovaných obranných pozícií je naznačený efektívny dostrel z nemeckého gul’ometu MG 42. Protitankové priekopy viditel'né na leteckých snímkach z roku 1950 sú znázornené hnedou líniou, ich predpokladaný priebeh je naznačený prerušovanou čiarou (grafická úprava: M. Neumann).

Fig. 5. Southeastern foreland of Buková Pass. Brown patches represent forests as in 1950. Identified field fortifications are denoted by letters (A - Všivavec hill and Smutná; B - Šarkan hill; C - Horný háj). Circles around each identified field fortification correspond with the effective range of German machine gun MG 42. Antitank ditches visible on orthophotos from 1950 are displayed as continuous brown lines; supposed antitank ditches are indicated as broken lines (graphics

by M. Neumann).

Orešian. Vrch Všivavec (256 m n. m.), cez ktorý viedol jeden zo vstupných koridorov do predpolia priesmyku, na svojej severnej strane pomerne strmo klesal do pril'ahlého údolia potoka Smutná. Podobne to platilo i o susednej polohe Políčko (obr. 3). Prechod cez vodný tok umožňovala len komunikácia vedúca z Horných Orešian do Neštichu (dnes Smolenická Nová Ves), prípadne úzke sedlo medzi vrchom Všivavec a susedným Políčkom, kde bolo možné prebrodit' potok Smutná. Nízky hrebeň, ktorý bol tvorený vrchom Všivavec a polohou Políčko, smerom na východ postupne klesal a strácal tak svoj obranný potenciál. Otváral sa tu tak priestor, ktorého obrana sa opierala o tok Trnávky a jej prítoky. Mohlo by sa zdat', že takýto spôsob zabezpečenia priestoru je nedostatočný, no treba vziat’ do úvahy špecifický terénny reliéf medzi Bolerázom a susednými Bíňovcami. Zúžený prietokový profil údolia v týchto miestach spôsoboval rozvodňovanie Trnávky i pri normálnych vodných stavoch a vytváral tak podmáčané územia široké miestami aj $800 \mathrm{~m}$ (Janšák 1961, 213). Podobné močariská sa tvorili aj d’alej po prúde Trnávky medzi Bolerázom a Klčovanmi, resp. Bohdanovcami a Trnavou. Východne od toku Trnávky vystupoval nad okolitý terén dominantný vrch Šarkan (274 m n. m.). Jeho severozápadný svah príkro klesal do blízkeho Bínovského potoka a účinne tak zamedzoval akémukol'vek prechodu t’ažkej bojovej techniky (obr. 5). Zo severovýchodu sa k jeho úpätiu upínal potok Krupica, resp. Krupský potok. Pozdĺž l’avého brehu Krupského potoka sa dodnes dvíha vysoký chrbát Horného hája (254 m n. m.), ktorý sa tiahne pozdĺž východného okraja obce Horná Krupá a v katastri blízkeho Naháča sa napája na masív Malých Karpát (vrch Lípie, 379 m n. m.). Prirodzenú obranu takto vyčleneného územia doplňo- 


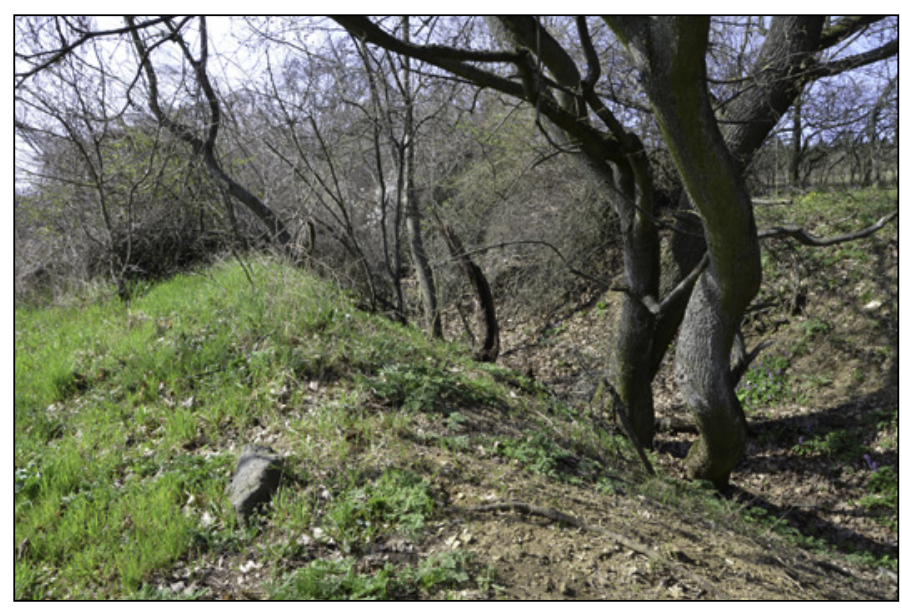

Obr. 6. Protitanková priekopa južne od vrchu Všivavec (foto: M. Neumann, apríl 2021).

Fig. 6. Antitank ditch south of Všivavec hill (photo by M. Neumann, April 2021).

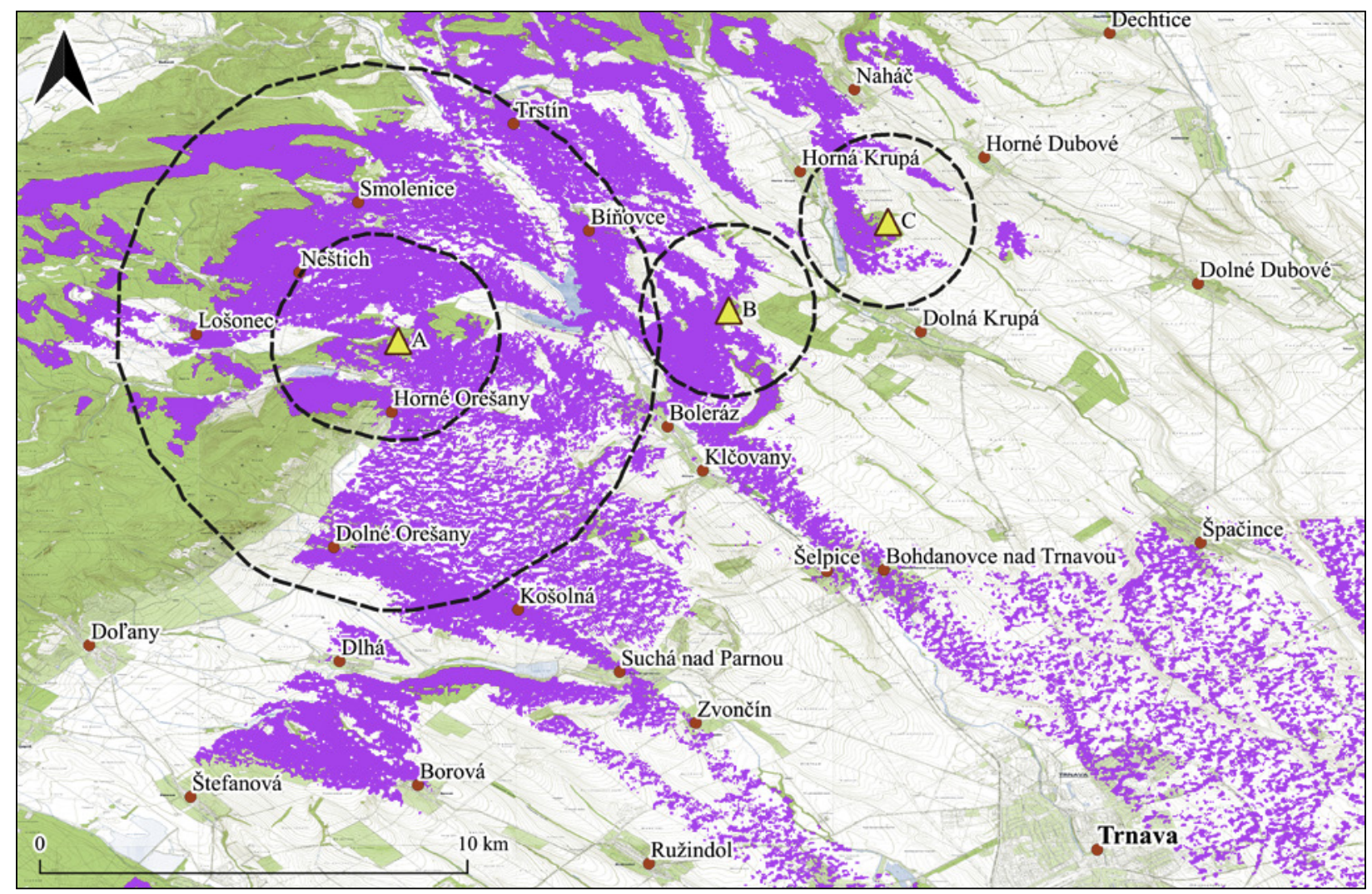

Obr. 7. Analýza viditel’nosti z pol'ného opevnenia na vrchu Všivavec (A). Viditel’né územie je vyznačené fialovou farbou. Identifikované relikty pol'ných opevnení sú označené písmenami (A - vrch Všivavec a poloha Smutná; B - vrch Šarkan; C - Horný háj). Pre každú z identifikovaných obranných pozícií je naznačený efektívny dostrel z nemeckého gulometu MG 42 (menší priemer), pre obranné stanovisko na vrchu Všivavec je naznačený aj efektívny dostrel z nemeckého mínometu GrW 42 (väčší priemer) (grafická úprava: M. Neumann).

Fig. 7. Viewshed analysis taken from the field fortification on Všivavec hill (A). Visible area is in purple. Identified field fortifications are denoted by letters (A - Všivavec hill and Smutná; B - Šarkan hill; C - Horný háj). Circles around each identified field fortification correspond with the effective range of German machine gun MG 42 (smaller circle), in case of Všivavec hill the effective range of German mortar GrW 42 (larger circle) is added (graphic improvement by 

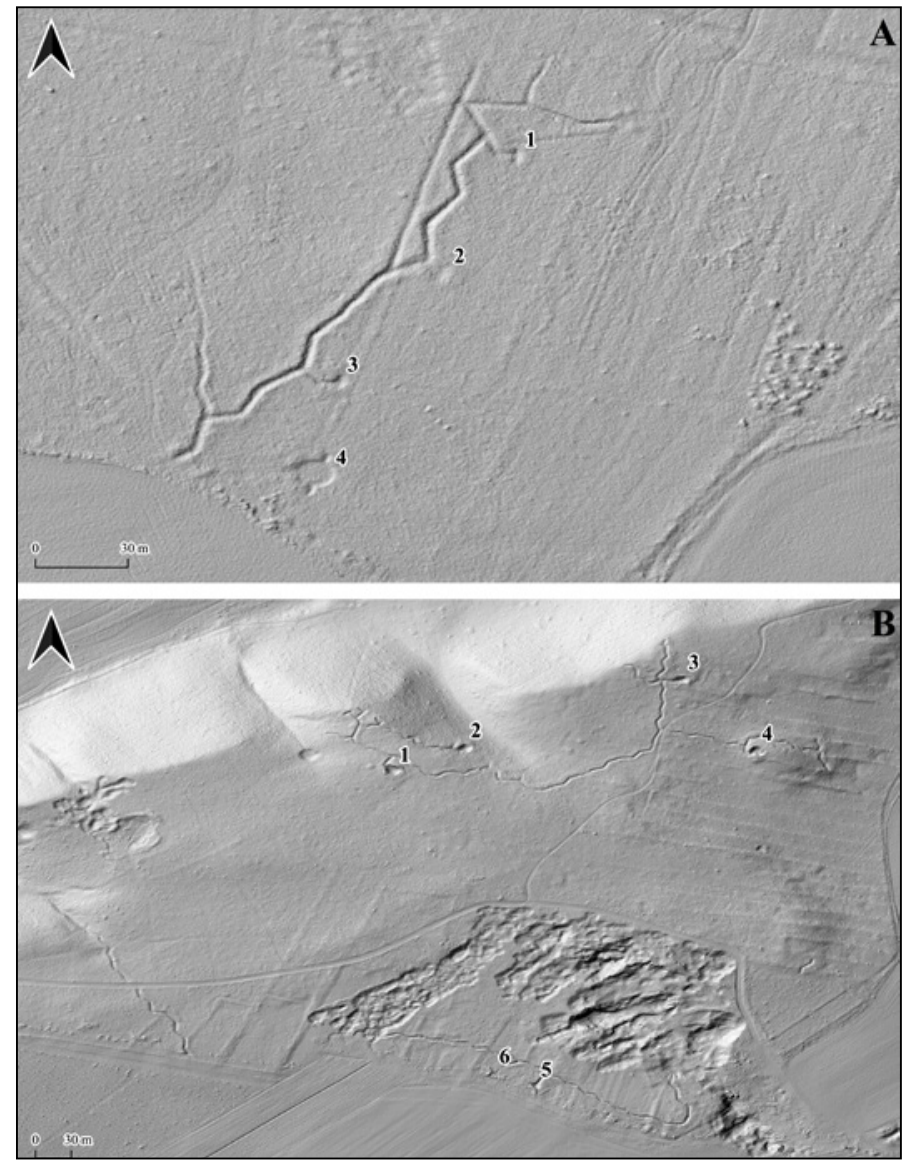

Obr. 8. A - Digitálny model terénu v polohe Smutná, severne od vrchu Všivavec. Línie zákopov sú doplnené o mínometné pozície (1-3) a pravdepodobne aj o stanovisko pre protitankové delo (4). B - Digitálny model terénu vrchu Všivavec. Zákopový systém je doplnený viacerými mínometnými pozíciami (1-6). V pravom dolnom rohu je viditel'ná čast' protitankovej priekopy. Zdroj produktov LLS: ÚGKK SR (grafická úprava: M. Neumann).

Fig. 8. A - Digital terrain model of Smutná, north of V̌̌ivavec hill. Trench lines are furnished with mortar positions (1-3) as well as one antitank cannon position (4). B - Digital terrain model of Všivavec hill. Trench system is furnished with more mortar positions (1-6). An antitank ditch is clearly visible in the bottom right corner. Source of LLS products: ÚGKK SR (graphics by M. Neumann).

chá nad Parnou (obr. 7). Ak budeme predpokladat', že nemeckí obrancovia používali obl'úbený a rozšírený gul’omet MG 42 s kadenciou 1550 rán za minútu a s účinným dostrelom až 2000 m, vedeli efektívne pokrývat' a kontrolovat' priamy vstup do Horných Orešian smerom od Trnavy (Bishop 1998, 247; Greentree 2018, 19). Terénne pozorovania, rovnako ako i lidarové snímky, naznačujú vd’aka prítomnosti kruhových depresií nasadenie aj d’alších zbraní - mínometov. V posledných rokoch vojny bol vo výzbroji Wehrmachtu najpoužívanejším pechotný $8 \mathrm{~cm}$ t’ažký mínomet typu GrW 42. V tomto prípade možno počítat’ s účinným dostrelom okolo 6 km (Haskew 2017, 100-101). To rozširovalo palebný rádius obrancov vrchu Všivavec až takmer po obec Košolná na juhu a po obec Boleráz na východe. Rovnako ako v predchádzajúcom prípade, aj táto oblast' bola bez akýchkol’vek problémov vizuálne kontrolovaná nemeckou posádkou priamo z vrchu Všivavec. vali aj početné lesné porasty, ktoré sú zachytené na spomínaných mapovaniach. Súvisle zarastené lesné plochy sa nachádzali v Igramskom háji, vo východnej časti vrchu Všivavec, v susednej polohe Políčko, v Dolnom háji v katastri obce Boleráz, na severovýchodnom svahu vrchu Šarkan a v Hornom háji severne od Dolnej Krupej (obr. 3, porovnaj s obr. 5). Neprekvapí, že čast' objavených pol'ných opevnení sa nachádzala v lesoch či na ich okraji. S vel'kou pravdepodobnost'ou tak boli využité ako istá forma maskovania či krytia.

Prírodné prekážky boli v predstihu doplnené o umelé prekážky, predovšetkým o protitankové priekopy. Okrem priamych očitých (písomných) svedectiev o ich prítomnosti v predpolí priesmyku svedčia opät' historické ortofotografie (obr. 5). Vd’aka nim možno identifikovat' takéto priekopy v blízkosti obce Naháč, odkial jedna z protitankových línií kopíruje z juhu cestu do Trstína. Hoci viditel'ná čast' priekopy sa stráca južne od polohy Prekážka, s pomocou satelitných snímok možno jej priebeh predpokladat' až do priestoru južne od obce Trstín. Potvrdzoval by to napokon i zápis z obecnej kroniky spomenutej obce (Kronika 1948, 1). V západnej časti predpolia priesmyku nie sú protitankové priekopy zachytené v takej dĺžke. Jediná priekopa, ktorú sa podarilo objavit' na leteckých fotografiách z roku 1950, ležala južne od vrchu Všivavec. V súčasnosti je priekopa husto zarastená a tvorí hranicu medzi dvoma susednými polami (obr. ఠ).

Posledným prvkom metódy KOCOA je pozorovanie a palebné pokrytie priestoru. Kvôli väčšej názornosti zameriame svoju pozornost' len na jednu z identifikovaných lokalít s pol’ným opevnením - na vrch Všivavec. Analýza viditel'nosti potvrdzuje nielen dostatočné pokrytie prístupového koridoru smerom z Horných Orešian ako aj severného okraja samotnej obce, no i celého priestoru medzi vrchom Všivavec a obcou Su- 
Kým prechod cez Všivavec bol bránený len pol’ným opevnením na tomto vrchu, brod cez potok Smutná medzi Všivavcom a Políčkom dodatočne chránilo aj pol’né opevnenie na okraji lesa v polohe Smutná. Dodnes sa z neho zachovala niekol'ko desiatok metrov dlhá lomená zákopová línia, ktorá bola v smere očakávaného príchodu protivníka doplnená o minimálne tri mínometné stanoviská (obr. $8 A$ ). Kruhová štruktúra pred zákopovou líniou, viditel’ná na lidarovom snímku (č. 4), je podobnou mínometnou pozíciou, resp. v súvislosti s jej vel'kost'ou možno uvažovat' aj o postavení pre protitankové delo.

\section{Interpretácia}

Identifikované relikty pol’ných opevnení v priestore medzi Trnavou a Trstínom sú zachované v dlhších, no i kratších úsekoch (obr. 9). V súlade s typológiou P. Šteinera možno objavené terénne relikty zaradit' k uceleným zákopovým systémom (vrch Všivavec, poloha Smutná) a samostatným zákopom (vrch Šarkan, Horný háj; Šteiner 2020a). Napriek uvedenému hendikepu je vo všetkých prípadoch zrejmé, že boli orientované voči útoku z juhovýchodu, teda zo smeru, odkial' sa na začiatku apríla 1945 blížila sovietska 1. gardová jazdecko-mechanizovaná brigáda. Takmer vo všetkých prípadoch boli objavené zákopové línie lokalizované na terénnych dominantách (Horný háj, Šarkan, Všivavec). Čast' z nich sa nachádzala $v$ lesnom poraste, čo možno interpretovat' ako premyslenú snahu o krytie či maskovanie vlastných postavení. Výpovednú hodnotu má aj skutočnost', že objavené zvyšky pol'ných opevnení sa dnes nachádzajú výhradne $\mathrm{v}$ zalesnených územiach, čo s vel'kou pravdepodobnost'ou výraznou mierou prispelo $\mathrm{k}$ ich relatívne dobrému zachovaniu. Hlbší analytický rozbor lokalizácie pol’ného opevnenia umožňuje najmä ucelený zákopový systém severne od Horných Orešian. Tvar zákopov na vrchu Všivavec i v polohe Smutná zodpovedá ideálnej dispozícii a usporiadaniu, ktoré možno nájst' v odporúčaniach príručky pevnostného stavitel'stva pre nemecký Wehrmacht (Oberkommando des Heeres 1944, Blatt 1; Fleischer 2004, 30). Zákopové línie sú vedené paralelne s predpokladaným vedením bojovej línie (obr. 8). Potvrdzuje to predpoklad, že pol'né opevnenie na vrchu Všivavec bolo zamerané na obranu jedného zo vstupných koridorov do predpolia Bukovského priesmyku. Vizuálne i palebne boli pokryté obe varianty prechodu cez potok Smutná - cesta z Horných Orešian do Smoleníc, ako aj úzke údolie vedúce $\mathrm{k}$ menšiemu brodu medzi Všivavcom a polohou Políčko (obr. 11). Tento potenciálny prechod bol navyše bránený aj pol'ným opevnením v polohe Smutná,

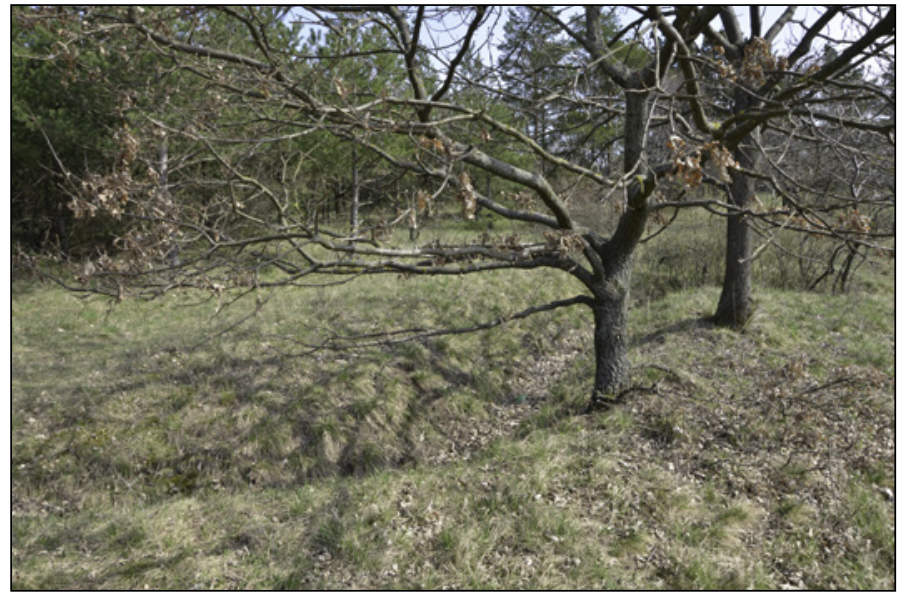

Obr. 9. Spojovacia zákopová línia na vrchu Všivavec (foto: M. Neumann, apríl 2021).

Fig. 9. Connecting trench line on Všivavec hill (photo by M. Neumann, April 2021).

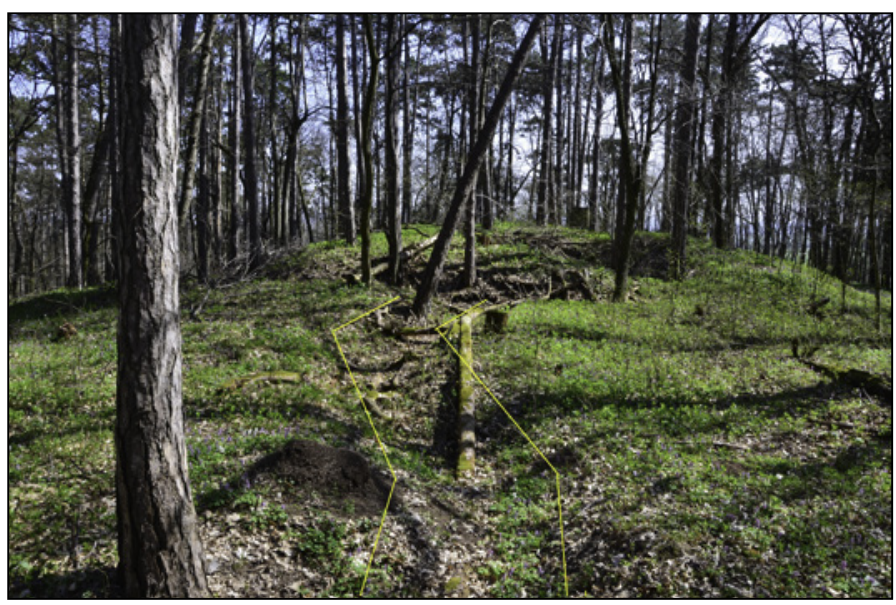

Obr. 10. Spojovací zákop vedúci k mínometnému stanovisku (zákop zvýraznený žltou farbou). Mínometné stanovisko je totožné s číslom 4 na obr. 8B (foto: M. Neumann, apríl 2021).

Fig. 10. Connecting trench heading to the mortar position (trench line highlighted in yellow). Mortar position is same as no. 4 on fig. 8B (photo by M. Neumann, April 2021). 


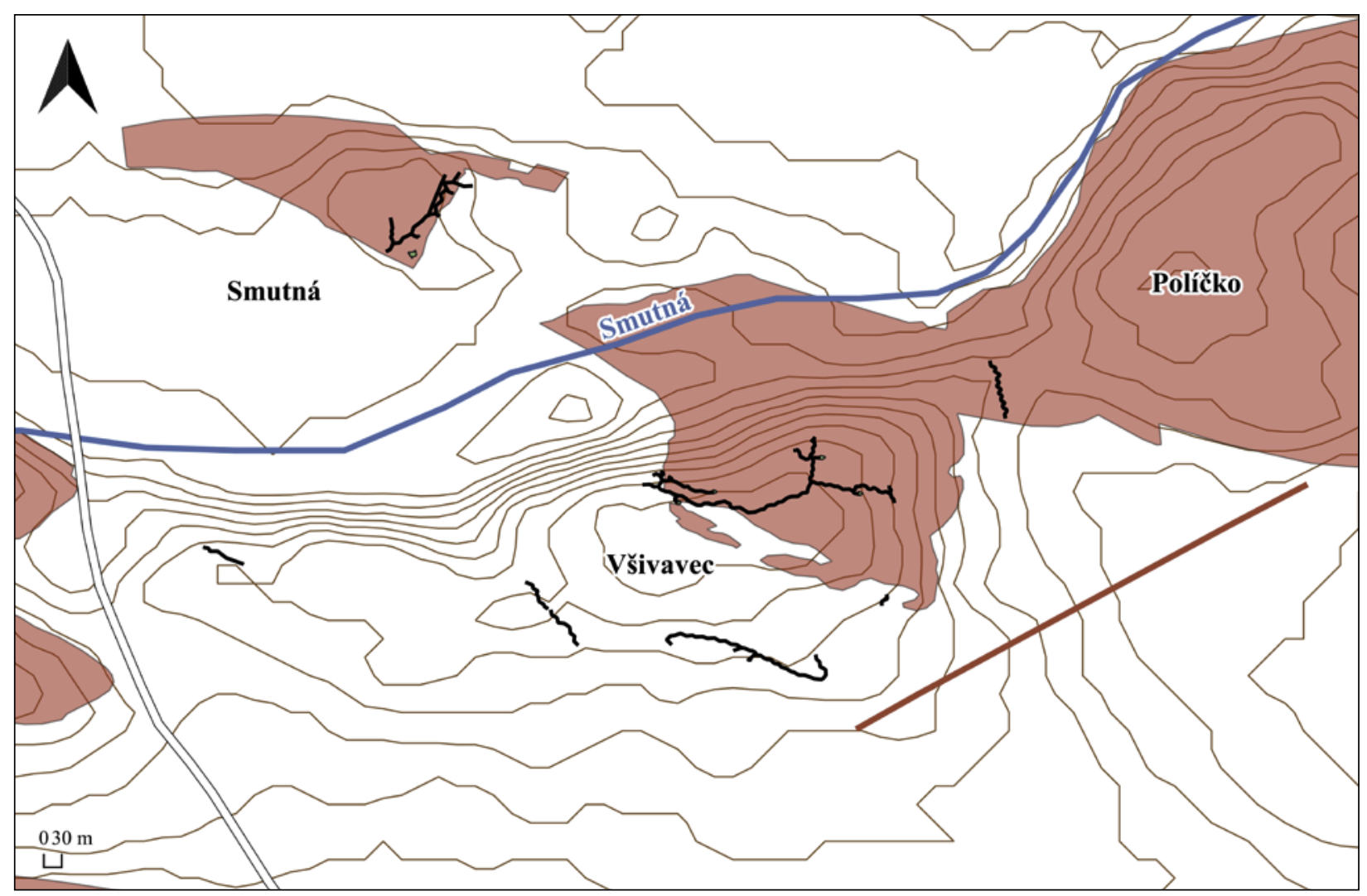

Obr. 11. Celková vizualizácia objavených pol’ných opevnení na vrchu Všivavec a v polohe Smutná. Západne od vrchu Všivavec vedie cesta z Horných Orešian do Neštichu (dnes Smolenická Nová Ves). Východne od Všivavca sa nachádza úzke údolie vedúce k brodu cez potok Smutná. Dlhá hnedá línia južne od polohy Políčko predstavuje protitankovú priekopu. Pôvodný lesný porast (stav z roku 1950) naznačený ružovou farbou (grafická úprava: M. Neumann).

Fig. 11w. General visualisation of identified field fortifications on Všivavec hill and Smutná. West of Všivavec leads a road from Horné Orešany to Neštich (today Smolenická Nová Ves). East of Všivavec lies a narrow valley leading to the ford on Smutná creek. Long brown line indicates an antitank ditch. Forests (pink) reconstructed according to the aerial photographs taken in 1950 (graphics by M. Neumann).

ktoré bolo ukryté tesne na kraji lesného porastu. Svojou orientáciou tiež potvrdzuje skutočnost', že účelom jeho vybudovania bola obrana spomínaného brodu. Zachované terénne relikty na vrchu Všivavec naznačujú, že nemeckí vojaci využívali na obranu predpolia Bukovského priesmyku mínomety (obr. 10). V tejto súvislosti je pozoruhodné, že frontová línia sa 1. apríla 1945 zastavila medzi obcami Košolná a Horné Orešany, čo korešponduje s efektívnym dostrelom mínometov z Všivavca. V predpolí vrchu Všivavec dopĺňala obranu mohutná protitanková priekopa. Jej pomerná blízkost' k predným zákopovým líniám (identifikovaným na lidarových snímkach i priamo v teréne) reflektuje nemeckú taktiku protitankovej obrany z konca 2. svetovej vojny (obr. 6; 8B). Rovnako aj prítomnost' d'alších výrazných terénnych prekážok - hustého lesa či strmého svahu - naznačuje, že pol’né opevnenie na vrchu Všivavec bolo intencionálne vybrané a pripravené na obranu pred tankovým útokom (Rottman 2005, 53). To isté možno konštatovat' aj o d’alších úsekoch hranice predpolia Bukovského priesmyku. Široký podmáčaný pás v okolí Trnávky, lesy v blízkosti vrchu Šarkan i v ned'alekom Hornom háji v kombinácii s výraznou morfológiou terénu mali plnit' podobnú funkciu. Absencia ucelených terénnych reliktov v posledne spomínaných lokalitách však zatial' nedovol’uje vytvárat' ucelenejšie závery. 


\section{Záver}

Ciel’om príspevku bolo poukázat' na možnosti metódy KOCOA pre výskum bojísk ako aj pri cielenom vyhl’adávaní terénnych reliktov po bojových činnostiach. Relatívne nenáročná priestorová analýza konkrétnych parametrov (klúčový terén, pozorovanie a palebné pokrytie priestoru, kryty a možnosti skrývania, prekážky, koridory prístupu) umožnila na náhodne zvolenom území medzi Trnavou a Trstínom identifikovat' viacero pol’ných opevnení. Tým preukázala svoj význam pri využití na cielené vyhl'adávanie terénnych reliktov (v tomto prípade spojených s bojovou činnost'ou).Výhodou pri nasadení tejto metódy je možnost' doplńania informácií z d’alších, nezávislých zdrojov - z písomných prameňov, očitých svedectiev priamych účastníkov, no predovšetkým z leteckých snímok, starých mapovaní a v súčasnosti najmä z údajov leteckého laserového skenovania (LiDAR). Práve lidarové snímky a identifikácia objavených reliktov priamo v teréne sa ukazujú ako nevyhnutný prostriedok pri práci s touto metódou. Dúfame, že pomerná nenáročnost’ aplikácie metódy KOCOA spoločne s jej potenciálnym informačným prínosom budú dostatočnou inšpiráciou pre jej akceptáciu aj v slovenskom prostredí.

\section{Bibliografia}

Babirát, M. 1996: Boleráz 1240-1995. Boleráz.

Bátora, J. - Drozd, D. 2019: Bojisko pri Vel'kých Vozokanoch - poznatky a perspektívy d’alšieho výskumu. Archaeologia historica 44, č. 2, 677-697.

Bishop, Ch. 1998: The Encyclopedia of Weapons of World War II. London.

Bordáć, M. 2017: Možnosti výskumu moderných militárií. Diplomová práca. Filozofická fakulta. Univerzita Konštantína Filozofa v Nitre. Nitra.

Bordáč, M. 2019: Nedeštruktívny výskum vybraných povstaleckých objektov stredoslovenského regiónu. In: Lofajová Danielová, B. - Furman, M. (eds.): Výsledky nových archeologických výskumov na strednom Slovensku II. a III. Zborník príspevkov z 2. a 3. ročníka konferencie archeológov pôsobiacich v oblasti stredného Slovenska, Banská Bystrica 2017 - Oravský Podzámok 2018. Dolný Kubín - Bratislava, 182-189.

Bordác, M. 2020a: Historical and archaeological evidence of a crashed American B-24 Liberator bomber near Trenčín. In: Drnovský, P. - Hejhal, P. (eds.): Archaeology of Conflicts. Hradec Králové, 195-206.

Bordác, M. 2020b: Metódy a formy výskumu moderných militárií. Dizertačná práca. Filozofická fakulta. Univerzita Konštantína Filozofa v Nitre. Nitra.

Brown, C. J. a kol. 2017: Fought under the walls of Bergida: KOCOA analysis of the Roman attack on the Cantabrian oppidum of Monte Bernorio (Spain). Journal of Conflict Archaeology 12, 2, 115-138.

Carrell, T. L. - Roth, M. J. - McKinnon, J. F. 2020: Fields of fire: Researching and modeling Peleliu's WWII invasion beaches. b. m.

Cendelín, D. 2019: Česká cesta jako součást staré dopravní sítě Slovenska - úsek Holíč-Bíňovce. Lokalizace historických tras v krajině a jejich relikty, komunikační souvislosti. Studia Historica Nitriensia 23, č. 1, 3-28.

Čambal, R. a kol. 2011: Záchranný výskum na trase podkarpatskej kanalizácie Pezinok - Chorvátsky Grob. Archeologické výskumy a nálezy na Slovensku 2008, 78-80.

Ciř̌, A. 1975: Smolenicko-chtelnické latifundium koncom 19. a začiatkom 20. storočia. In: Šimončič, J. (ed.): Trnavský zborník I. Bratislava, 150-174. 
Drahoš, J. 2006: Priemyselný rozvoj. In: Babirát, M. a kol. (ed.): Horné Orešany. Historicko-národopisná monografia. Horné Orešany, 103-107.

Drozd, D. 2019: Analysis of iconographic sources and its contribution to the research of an early modern battlefield - Vel'ké Vozokany. Poster. Konferencia Archeologie konfliktů, Hradec Králové 2019. Bratislava.

Drozd, D. - Neumann, M. - Bátora, J. 2020: Contribution of archaeological prospection to the research of an early modern battlefield near Vel'ké Vozokany. In: Kleinová, K. (ed.): 26 ${ }^{\text {th }}$ EAA Virtual Annual Meeting. Abstract Book. Praha, 483.

Engler, M. 2017: Železnice v okolí Smoleníc a Dobrej Vody. Trnava.

Fleischer, W. 2004: Feldbefestigungen des deutschen Heeres 1939-1945. Eggolsheim.

Greentree, D. 2018: Hitlerjugend soldier vs Canadian soldier. Normandy 1944. London.

Haskew, M. E. 2017: Zbrane druhej svetovej vojny. Praha.

Hešsterová, Z. 2015: Zbrojársky priemysel na strednom Považí v rokoch 1939 - 1941 (od vzniku Slovenského štátu do vojny proti Sovietskemu zväzu). In: Mičko, P. - Hallon, L. a kol. (eds.): Lesk a tiene hospodárskeho rozvoja Slovenska v rokoch 1939 - 1941. Kraków - Banská Bystrica, 183-205.

Horváth, P. 1987: Trnava v období socializmu I. In: Šimončič, J. (ed.): Trnava 1238 - 1988. XVI. vlastivedný seminár v Trnave 20. mája 1987. Referáty. Trnava, 48-63.

Hošek, A. 2018: Archeologické doklady bojovej činnosti v juhozápadnej časti Štiavnických vrchov v rokoch 1944 a 1945. Bakalárska práca. Filozofická fakulta Univerzity Komenského v Bratislave. Bratislava.

Hošek, A. 2019: Archeologické doklady bojovej činnosti v juhozápadnej časti Štiavnických vrchov v rokoch 1944 a 1945. Musaica archaeologica 4, č. 2, 173-193.

Hošek, A. 2020: Identifikácia, klasifikácia a výskum archeologických komponent z obdobia druhej svetovej vojny na Slovensku. Diplomová práca. Filozofická fakulta Univerzity Komenského v Bratislave. Bratislava.

Janšák, Š. 1961: Z minulosti rybnikárstva na potoku Trnávke. Geografický časopis 13, č. 3, 212-222.

Janšák, Š. 1963: Biela hora v Malých Karpatoch. Geografický časopis, 15, č. 3, 186-196.

Janšák, Š. 1986: Brány do dávnoveku. Bratislava.

Jastrabik, S. 1975: Smolenice. Bratislava.

Jordan, F. 2015: April 1945. Die Kämpfe im nordöstlichen Niederösterreich. Salzburg.

Kim, K. O. a kol. 1994: Development of a tactical terrain analysis system with GIS technique. Proceedings of IGARSS '94 - 1994 IEEE International Geoscience and Remote Sensing Symposium, Vol. 2, 860-862.

Kronika 1948 - Kronika obce Trstín - roky 1945 - 1948. Trstín.

Ko ̌̌uch, P. 1965: V tyle nepriatel’a. In: Trnava vd’ači za oslobodenie slávnej Sovietskej armáde. Trnava, 2-9.

Krivánek, R. - Čech, P. - Soukup, M. 2015: Geophysical prospection and rescue archaeological excavation of subsurface WWII remains in the foreland of brown coal mines in northwestern Bohemia. Archaeologia Polona 53, 217-222.

Mabler, O. - Broft, M. 1984: Bratislavsko-brněnská a ostravská operace. Historie a vojenství 33, č. 4, 59-81. 
Majer, F. 2018: Archeologické doklady bojovej činnosti na Hornom Pohroní v rokoch 1944 a 1945. Bakalárska práca. Filozofická fakulta Univerzity Komenského v Bratislave. Bratislava.

Mastone, V. T. - Brown, C. J. - Maio, Ch. V. 2015: The revolutionary war battle of Chelsea Creek - grounding the historical narrative throught cultural landscape analysis. Northeast Anthropology 83-84, 155-176.

Matoušek, V. 2017: Archeologický výzkum bojišt' a vojenství raného novověku v českých zemích. Historie, stav poznání, diskuse. Archaeologia historica 42, č. 1, 233-243.

Mišuth, V. 2014: Suchá nad Parnou. Za zabudnutou minulost’ou. Bratislava.

Nejedlý, M. 1978: Plány nacistického Wehrmachtu a prostor Československa 1944-1945 (II.). Historie a vojenství 27, č. 6, 40-57.

Nesvadba, F. - Plubař, J. 1962: Osvobození jihozápadního Slovenska a jižní Moravy 2. ukrajinským frontem na jaře r. 1945. Historie a vojenství 11, č. 1, 30-70.

Oberkommando des Heeres 1944: Bildheft Neuzeitlicher Stellungsbau vom 1. Juni 1944. Hauptquartier.

Pauliak, E. 1980: Cesty slobody k Bratislave. Bratislava.

Plijev, I. A. 1975: V Československu (9). Obrana lidu 34, č. 20, 9.

Rak, M. 2010: Aeroarcheologie - výzkum havarovaných letounů. Acta Fakulty filozofické Západočeské univerzity v Plzni 4/10, 249-265.

Rak, M. 2013: Archeologie konfliktů 20. století. In: Vařeka, P. (ed.): Archeologie 19. a 20. století. Přístupy - metody - témata. Plzeň, 115-136.

Rak, M. 2014: Archeologie konfliktů 20. století. Aeroarcheologie. Historie - témata - metody - př́klady. Plzeň.

Rottman, G. L. 2005: World War II Infantry Anti-Tank Tactics. Oxford - New York.

Scott, D. - McFeaters, A. P. 2011: The archaeology of historic battlefields: A history and theoretical development in conflict archaeology. Journal of Archaeological Research 19, 103-132.

Sivilich, M. 2012: A proposed model to investigate the role of education in the success of military strategy in Florida during the Second Seminole War (1835-1842). Historical Archaeology 46 (1), 62-73.

Sivilich, E. D. - Sivilich, D. M. 2015: Surveying, statistics, and spatial mapping: KOCOA landscape analysis of eighteenth-century artillery placements at Monmouth Battlefield State Park, New Jersey. Historical Archaeology 49 (2), 50-71.

Spennemann, D. 2020: Using KOCOA Military Terrain Analysis for the Assessment of the Twentieth Century Battlefield Landscapes. Heritage 3, 753-781.

Spily, P. - Hrnčiar, M. 2013: Vojenská taktika. Vysokoškolská učebnica. Liptovský Mikuláš.

Stelzl-Marx, B. 2012: Stalins Soldaten in Österreich. Die Innensicht der sowjetischen Besatzung 1945-1955. Wien München.

Šimončič J. 1979: Oslobodenie Trnavského okresu. In: Žvach L. - Packa, L. (zost.): Protifašistický odboj v okrese Trnava. Bratislava, 201-219.

Šteiner, P. 2020a: Identifikácia polných opevnení z druhej svetovej vojny na juhozápadnom Slovensku a náčrt ich typológie. Musaica archaeologica 5, č. 2, 87-94. 
Šteiner, P. 2020b: Výskum bojísk druhej svetovej vojny na juhozápadnom Slovensku. Východiská a perspektívy. In: Kozubová, A. - Makarová, E. - Neumann, M. (eds.): Ultra velum temporis. Slovenská archeológia - Supplementum 1. Nitra, 567-574.

Steiner, P. 2020c: Possibilities of archaeological research on the World War II battlefield in Slovakia. In: Drnovský, P. - Hejhal, P. (eds.): Archaeology of Conflicts. Hradec Králové, 207-222.

Vařka, P. 2018: Archeologický výzkum tábora v Letech. Archeologie modernity a výzkum táborů z druhé světové války. Dějiny a současnost 4, 10-14.

Vařeka, P. - Vařeková, Z. 2017: Archeologický výzkum tábora v Letech. Bulletin Muzea romské kultury 26, 59-83.

Woeblke, S. - Hollon, D. 2011a: 1791 Battle of the Wabash: Battlefield boundaries, battle details and KOCOA analysis. In: Keller, Ch. et al. (eds.): Archaeology of the battles of Fort Recovery, Mercer county, Ohio: Education and protection. Muncie, 62-72.

Woeblke, S. - Hollon, D. 2011b: 1794 Battle of Fort Recovery: Battlefield boundaries, battle details and KOCOA analysis. In: Keller, Ch. et al. (eds.): Archaeology of the battles of Fort Recovery, Mercer county, Ohio: Education and protection. Muncie, 73-77.

Zubalik, J. 2019: Field fortifications from the Second World War: possibilities of archaeological research on post-military landscapes in South Moravia (Czech Republic). AUC Geographica 55 (1), 77-92.

- my - 1991: Jedna udalost' - jedna výstava. Múzeum 1, 50.

\section{Internetové zdroje}

http://www.kpt.sk/clanky/opevnenia-v-malych-karpatoch-z-druhej-svetovej-vojny.html (navštívené 30. 6. 2021) http://www.pamiatky.sk/sk/page/aktuality-kpu-trnava (navštívené 30. 6. 2021)

https://ct24.ceskatelevize.cz/3352658-nadsenci-na-osoblazsku-vykopali-stary-havarovany-sturmovik-rusky-bitevnik-byl-ctyri-metry (navštívené 30. 6. 2021)

https://www.leteckemuzeum.eu/ (navštívené 30. 6. 2021)

https://www.mhmo.sk/ (navštívené 30. 6. 2021)

\section{Mapové podklady}

https://earthexplorer.usgs.gov/

http://mapy.tuzvo.sk/hofm/default.aspx

https://www.geoportal.sk/sk/sluzby/mapove-sluzby/wms/

https://www.geoportal.sk/sk/sluzby/aplikacie/mapovy-klient-zbgis/

\section{Summary}

The aim of this article was to demonstrate the possibilities of KOCOA analysis for prediction of battlefield relics. Relatively simple spatial analysis operating with a few attributes (key terrain, observation and fields of fire, concealment and cover, obstacles, avenues of approach) was able to predict places with probable presence of WWII field fortifications. In this paper the region between Trnava and Trstín (SW Slovakia) was chosen as the model area. As a result, field fortifications were discovered in cadastres of Horné Orešany (Všivavec hill), Smolenická Nová Ves (site Smutná), Boleráz (Šarkan hill) and Dolná Krupá (site Horný háj). These could have been identified as trenches, mortar positions, antitank cannon position and antitank ditch. Their position in landscape clearly reflects their aim - 
to protect the main communication lines leading to the Buková Pass in Small Carpathians which allowed the easiest connection between Záhorie region (by then under control of German army) and the rest of SW Slovakia (being actually swiftly swept by the $2^{\text {nd }}$ Ukrainian Front). The results of this method can be confronted with (and complemented by) other independent historical sources - testimonies of direct eye-witnesses, military reports, old maps and LiDAR-derived images. However, it seems that LiDAR-derived images together with direct identification of terrain relicts present the crucial points in the whole evaluation process. Nevertheless, the interplay of all accessible sources should always be taken into account to offer a satisfying result. We hope that this simple method and its information asset will increase its acceptance and will inspire further research in Slovak archaeology. 